\title{
MULTILINGUALISM
}

\section{IN ANCIENT CONTEXTS}

\section{Perspectives from Ancient Near Eastern and Early Christian} Contexts

EDITORS

Louis C. Jonker Angelika Berlejung Izak Cornelius 


\section{DIGLOSSIA AND THE} NEO-ASSYRIAN EMPIRE'S

\section{AKKADIAN AND ARAMAIC \\ TEXT PRODUCTION}

Karen Radner

LMU Munich 


\subsection{MULTILINGUAL, DIGRAPHIC, AND DIGLOSSIC}

The Neo-Assyrian period is the time from ca.900-600 BCE when the Middle East and the Eastern Mediterranean were politically and culturally dominated by the NeoAssyrian Empire, ${ }^{1}$ whose heartland in the triangle between the cities Assur (Qal'at Sherqat), Nineveh (Mosul), and Arbail (Erbil) corresponds to northern Iraq and whose core population spoke Neo-Assyrian, a dialect of Akkadian of the Semitic language family. ${ }^{2}$ Since the restructuring of the state under Ashurnasirpal II (884-859 BCE), which brought the king to the fore, the imperial palace was unequivocally the heart of the Neo-Assyrian Empire, with the widely publicised move of the court away from Assur to the new capital city of Kalhu constituting the deliberate beginning of a new era. ${ }^{3}$

By the second half of the 8th century BCE, the Empire formed a highly multilingual environment, ${ }^{4}$ as the provinces of this sizable and complex state encompassed regions in modern Iran, Turkey, Syria, Lebanon, Israel, and Jordan where various Semitic languages (including Aramaic, Phoenician, Hebrew, and Arabic) and non-Semitic languages (e.g., the Indo-European languages Luwian and Median; the Hurrian languages Šubrian and Urartian; and the isolates Mannean and Elamite) were spoken.

Routine resettlement of large population groups across the holdings of the Empire ${ }^{5}$ caused further dissemination of these language but also massively strengthened the use of the more widely spoken and moreover mutually understandable Semitic languages.

At the same time, the Neo-Assyrian Empire was to be the last state ever to sponsor writing in the traditional cuneiform script and the Akkadian language on all levels of its administration. Firmly embedded in state-sponsored communication and governance

Recent surveys of the historical development of the Neo-Assyrian Empire include Karen Radner, "The Neo-Assyrian Empire", in Imperien und Reiche in der Weltgeschichte: Epochenübergreifende und globalhistorische Vergleiche, eds. Michael Gehler \& Robert Rollinger (Wiesbaden: Harrasowitz, 2014), 101-20; Mario Liverani, Assyria: The Imperial Mission (Winona Lake: Eisenbrauns, 2017); and the relevant chapters in Eckart Frahm, ed., $A$ Companion to Assyria (Hoboken: Wiley-Blackwell, 2017).

On "Neo-Assyrian", as we call the variant of Assyrian used in the Neo-Assyrian period today, see Mikko Luukko \& Greta van Buylaere, "Languages and Writing Systems in Assyria", in A Companion to Assyria, ed. Eckart Frahm (Hoboken: Wiley-Blackwell, 2017), 313-14, 316-18.

3 As discussed in Karen Radner, "The Assur-Nineveh-Arbela Triangle: Central Assyria in the Neo-Assyrian Period", in Between the Cultures: The Central Tigris Region in Mesopotamia from the 3rd to the 1st Millennium BC, eds. Peter Miglus \& Simone Mühl (Heidelberg: Heidelberger Orient-Verlag, 2011), 324-25.

4 Cf. Luukko \& Van Buylaere, "Languages and Writing Systems in Assyria", 320-21.

5 Most recently discussed by Karen Radner, "The 'Lost Tribes of Israel' in the Context of the Resettlement Programme of the Assyrian Empire", in The Last Days of the Kingdom of Israel, eds. Shigeo Hasegawa, Christoph Levin \& Karen Radner (Berlin: De Gruyter, 2018), 101-23. 
programmes, ancient Mesopotamian writing practices and textual traditions were able to blossom to a degree that is unprecedented - before and after. The culmination is arguably the royal library of Nineveh, today often called "Assurbanipal's library", which was assembled in the last Assyrian capital over the course of the 7th century $\mathrm{BCE}^{6}$ and constitutes the most voluminous repository of texts to survive from the Neo-Assyrian Empire. However, texts in cuneiform script were produced not just in the capital or in the heartland, but all over the Empire, as finds from well over 30 sites demonstrate. ${ }^{7}$ Given the Empire's expansive reach, cuneiform texts were once again composed in regions in what are today Iran, Turkey, Syria, Lebanon, Israel, and Jordan - areas that had left the cultural koiné of the Bronze Age cuneiform world centuries ago.

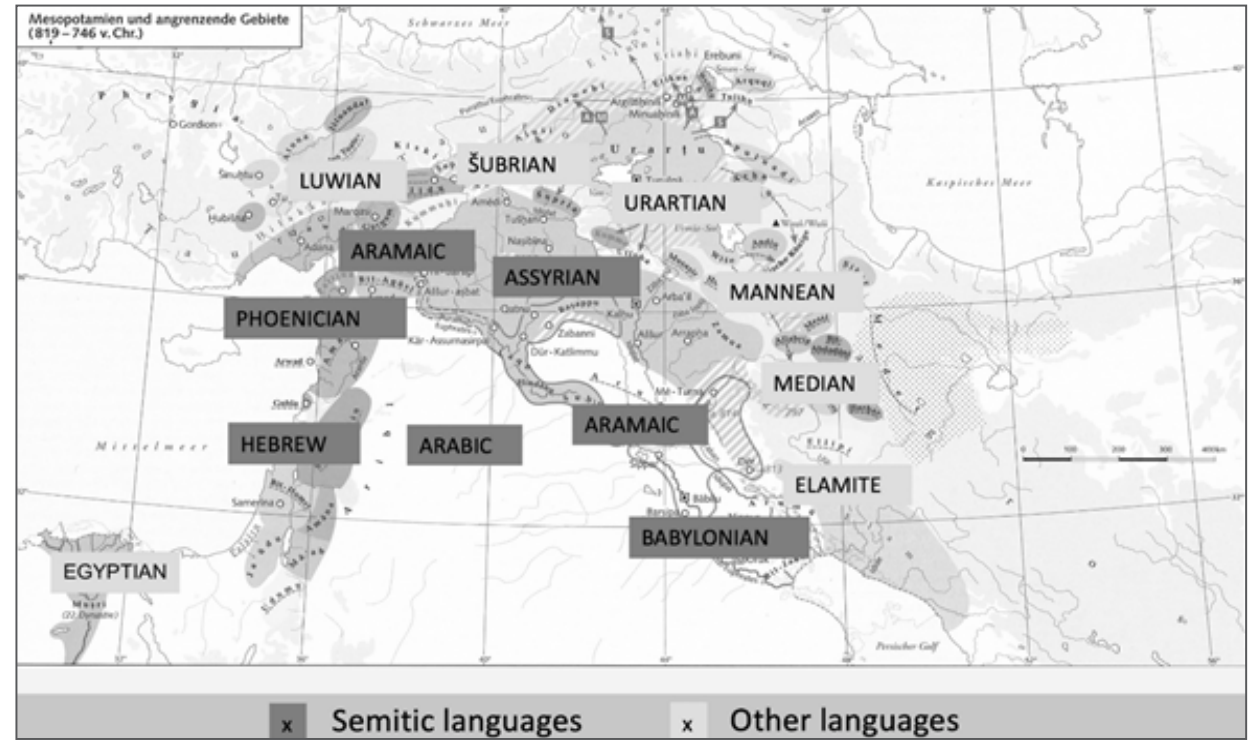

FIGURE 9.1 The many languages of the Neo-Assyrian Empire

On the royal libraries at Nineveh, see Jeanette C. Fincke, "Assyrian Scholarship and Scribal Culture in Kalhu and Nineveh", in A Companion to Assyria, ed. Eckart Frahm (Hoboken: WileyBlackwell, 2017), 385-94. On specifically Assurbanipal's library, see also David Damrosch, The Buried Book: The Loss and Rediscovery of the Great Epic of Gilgamesh (New York: Henry Holt \& Company, 2006), 81-114.

7 See the maps by Karen Radner, "Schreiberkonventionen im assyrischen Reich: Sprachen und Schriftsysteme", in Assur: Gott, Stadt und Land, ed. Johannes Renger (Wiesbaden: Harrassowitz, 2011), 395 Figure 4 (but delete Choga Gavaneh in western Iran, whose supposedly Neo-Assyrian tablets turned out to be Old Babylonian material upon publication by Kamyar Abdi \& Gary Beckman, "An Early Second-Millennium Cuneiform Archive from Chogha Gavaneh, Western Iran", Journal of Cuneiform Studies, 59 [2007]: 39-91) and by Poppy Tushingham, "Uniformity versus Regional Variation in the Legal and Scribal Practices of the Neo-Assyrian Empire", Zeitschrift für Altorientalische und Biblische Rechtsgeschichte, 25 (2019): 31 (only mapping sale documents but adding also the newly found texts from Marqasu = Kahramanmaraș in Turkey and Tell Sitak and Qalat-i Dinka in the Kurdish Autonomous Region of Iraq). 
Despite its promotion of the cuneiform script from the late 9th century BCE onwards, the Empire used a digraphic double-copy system to document information in Akkadian and Aramaic. The Aramaic language and script came to be used by the imperial administration in direct consequence of the Empire's integration of Aramaicspeaking polities, as the scribes serving these states were now incorporated into the Assyrian administrative structures, just like the defeated soldiers were added to the imperial armies. The use of Aramaic is well documented in the Assyrian heartland from the reign of Shalmaneser III (r. 858-824 BCE) onwards.

The best evidence is provided by the letters of the Aramaic alphabet painted on the glazed bricks of Shalmaneser's military palace ("arsenal") in his capital city of Kalhu, probably as fitters' marks. ${ }^{8}$ The earliest Assyrian depiction of a scribe writing in alphabet script with a pen on a leather scroll, alongside a cuneiform scribe with a stylus and tablet, dates to his reign too. ${ }^{9}$ As identified by a cuneiform caption accompanying the scene, the two scribes record the tribute of the king of Unqu, a client state of the Empire centred on the Amuq plain in northwestern Syria, as it is being brought before the Assyrian king.

Similar depictions of the pair of scribes (with the cuneiform scribe either holding a clay tablet or a writing board) are common in the wall decorations of the Assyrian palaces of the 8th and 7th centuries BCE, always in the administrative context of registering spoils of war, booty, or tribute, typically in the aftermath of battle. ${ }^{10}$ Such scenes indicate that the two scribes working in tandem record in double copy sensitive information about people and valuable resources while working far away from the imperial centre. Having two people register the same data separately with two distinct recording systems is an effective way to prevent tampering and minimise collusion. It therefore constitutes a highly efficient security protocol that would have enabled the central administration to place more trust into its far-away agents and the information they produced. The practice is closely paralleled by the way the Empire employed teams using divination disciplines from different cultural contexts to foretell the future, thereby acting as each other's control groups (notably, extispicy, the study of livers from sacrificial sheep in the Mesopotamian tradition, versus augury, the interpretation of Balawat in 1989", Iraq, 55 (1993), 35-36, with figures 21-26.

The scene is depicted on one of the decorated bronze bands holding together the wooden doors of the temple in Imgur-Ellil (modern Balawat) in the Assyrian heartland, see Andreas Schachner, Bilder eines Weltreichs: kunst- und kulturgeschichtliche Untersuchungen zu den Verzierungen eines Tores aus Balawat (Imgur-Enlil) aus der Zeit von Salmanassar III, König von Assyrien (Turnhout: Brepols, 2007), pl. 5 (individuals 23 and 24 on Band V). 
bird flight in the Syro-Anatolian tradition, and later also oneiromancy, the divination by means of dream interpretation in the Egyptian tradition). ${ }^{11}$

That the multilingual Neo-Assyrian Empire operated a digraphic recording system that made use of cuneiform and the alphabet has long been appreciated. ${ }^{12}$ But we have to recognise that Akkadian was recorded in cuneiform in three distinct variants. On the one hand, (1) Standard Babylonian (in German, "Jungbabylonisch") was a highly codified literary language (or "high" variety) that was modelled on an ancient form of Babylonian as used ca. 1500 BCE; acquired in the course of a highly specialised education, it was used for scholarship as well as works of poetry and literature (including royal inscriptions). On the other hand, (2) Neo-Assyrian and (3) NeoBabylonian were vernacular language varieties (or "low" varieties), as actively spoken at the time especially in northern and southern Mesopotamia, respectively. Moreover, from the moment that (4) Aramaic played a role in the Assyrian state administration it should be seen as a third vernacular language employed in the service of the Empire.

As this chapter aims to highlight, the Empire's language environment, and in particular its scribal production, was diglossic with a sharp distinction between the highly codified literary language of Standard Babylonian for high status texts and three vernacular languages for lower status communications. ${ }^{13}$ I would argue that between these languages, the distinction between the highly codified lect on the one hand and the three vernacular languages on the other hand is far more significant than the fact that three of these languages were written in cuneiform and the other in alphabetic script.

For the practitioners of the Egyptian and Syro-Anatolian prognostic and therapeutic disciplines in the employ of the Assyrian state see Karen Radner, "The Assyrian king and his scholars: The Syro-Anatolian and the Egyptian Schools", in Of God(s), Trees, Kings, and Scholars: NeoAssyrian and Related Studies in Honour of Simo Parpola, eds. Mikko Luukko, Sanna Svärd \& Raija Mattila (Helsinki: Finnish Oriental Society, 2009), 221-38. For these scholars serving as "control groups" for the experts working in the Mesopotamian traditions see Karen Radner, "Royal Decision-Making: Kings, Magnates, and Scholars", in The Oxford Handbook of Cuneiform Culture, eds. Karen Radner \& Eleanor Robson (Oxford: Oxford University Press, 2011), 367.

Cf. e.g., Betina Faist, "Sprachen und Schriften in Assur", in Wiedererstehendes Assur. 100 Jahre deutsche Ausgrabungen in Assyrien, eds. Beate Salje \& Joachim Marzahn (Mainz: Zabern, 2003), 149-56 (with illustrations in colour) and Frederick Mario Fales, "Multilingualism on Multiple Media in the Neo-Assyrian Period: A Review of the Evidence", State Archives of Assyria Bulletin, 16 (2007), 95-122.

For the phenomenon of diglossia and the linguistic terminology used to describe it, see Charles A. Ferguson, "Diglossia", Word, 15 (1959): 325-40. For a recent general discussion of diglossia in the ancient Near East, see Rebecca Hasselbach-Andee, "Multilingualism and Diglossia in the Ancient Near East", in A Companion to Ancient Near Eastern Languages, ed. Rebecca Hasselbach-Andee (Hoboken: Wiley-Blackwell, 2020), 457-70, with 463-65 focusing on Akkadian and Aramaic. 


\subsection{DIFFERENT MODES OF SCRIBAL TRAINING}

The Assyrian state played a prominent role in the production and transmission of cuneiform writing, both directly and indirectly. From the available sources, it is obvious that many Neo-Assyrian period cuneiform scribes shared a common professional setting and educational background that led, e.g., to the use of a highly standardised set of cuneiform characters, in particular to represent words (logograms), and to very uniform formatting conventions for the clay tablets. Yet, how precisely cuneiform practitioners of different levels of competence and expertise were trained and interacted professionally is only poorly understood.

Exercise tablets documenting the first steps of scribal training survive in relatively small numbers and have typically been excavated in private contexts. ${ }^{14}$ Such tablets unequivocally demonstrate that the traditional Mesopotamian practice of homeschooling continued. Such training received within the family likely underpinned much of the scribal education of future scholars who were typically born into families with a distinct tradition, which they tend to proudly celebrate in the genealogies detailed in the "colophons" of their tablets. ${ }^{15}$ In the later stages of training, learning by doing under the tutelage of an expert was clearly considered essential, with therapeutic and prognostic specialists working in teams composed of master and trainee practitioners: "The apprentices should imitate and assist them" as a letter from the 7 th-century royal correspondence states in regard to astrologers. ${ }^{16}$

For a preliminary survey, see Petra D. Gesche, Schulunterricht in Babylonien im ersten Jahrtausend v. Chr. (Münster: Ugarit-Verlag, 2001), 23-24. The most important body of sources are the scribal exercises found in private houses in the city of Assur, which are to be published in a forthcoming volume edited by Stefan M. Maul (Schülerübungen aus neuassyrischer Zeit, to appear as part of the series Keilschrifttexte aus Assur literarischen Inhalts, Wiesbaden: Harrassowitz). Note also the bilingual (Sumerian-Akkadian) scribal exercise that was excavated in an 8th century BCE context at Dur-Katlimmu (Tell Sheikh Hamad): Karen Radner, "Neue neuassyrische Texte aus Dūr-Katlimmu: Eine Schülertafel mit einer sumerisch-akkadischen Königshymne und andere Keilschriftfunde aus den Jahren 2003-2009", in Dür-Katlimmu 2008 and Beyond, ed. Hartmut Kühne (Wiesbaden: Harrossowitz, 2010), 178-80, no. 4.

15 For the pride of the scholarly families in their ancestry, see Karen Radner, "Royal DecisionMaking: Kings, Magnates, and Scholars", in The Oxford Handbook of Cuneiform Culture, eds. Karen Radner \& Eleanor Robson (Oxford: Oxford University Press, 2011), 363. The most accessible collection of colophons is still Hermann Hunger, Babylonische und assyrische Kolophone (Kevelaer: Butzon \& Bercker/Neukirchen-Vluyn: Neukirchener Verlag des Erziehungsvereins, 1968). For a detailed study of one scholar's colophons, see Natalie Naomi May, "The Scholar and Politics: Nabû-zuqup-kēnu, his Colophons and the Ideology of Sargon II", in Proceedings of the International Conference Dedicated to the Centenary of Igor Mikhailovich Diakonoff (1915-1999), ed. Natalya V. Koslova (St. Petersburg: The State Hermitage Publishers, 2018), 110-64.

16 Simo Parpola, Letters from Assyrian and Babylonian Scholars. State Archives of Assyria 10 (Helsinki: Helsinki University Press, 1993), no. 385 rev. 1-3. 
The scribal training received by state officials was certainly much less exhaustive than the education of highly educated specialists who needed to be able to master the full arsenal of the cuneiform script, including understanding the dead Sumerian language. Nevertheless, the officials' education had to be comprehensive enough to enable them to read and write cuneiform on a level that required command of the syllabic and logographic spellings typically used in legal documents, administrative texts and letters. That this was generally achieved is demonstrated by the original letter of one such official, who had a posting in the eastern regions of the Empire in the last part of the 8th century BCE. At some point, he found himself without the secretaryscribe that typically came with his position and he personally, without recourse to any professional assistance, was able to communicate his urgent need of a scribe to the king, which he clearly saw as an indispensable support in fulfilling his own role.

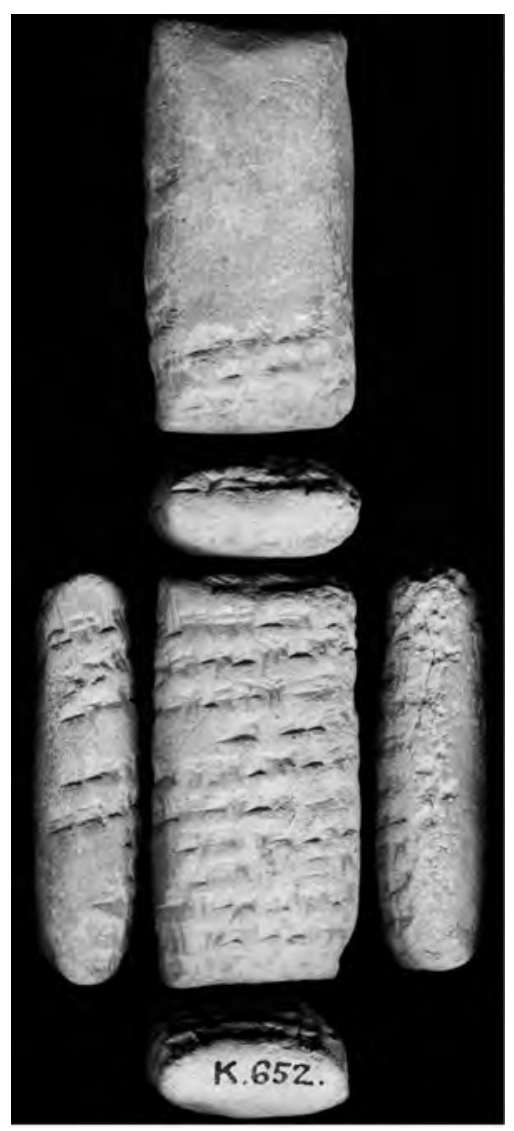

FIGURE 9.2 A cuneiform letter written by a state official in need of a scribe ${ }^{17}$

17 Andreas Fuchs \& Simo Parpola, The Correspondence of Sargon II, Part III: Letters from Babylonia and the Eastern Provinces. State Archives of Assyria 15 (Helsinki: Helsinki University Press, 2001), no. 17. 
Despite ordinarily relying on a secretary-scribe, this man was perfectly capable of doing the job of reading and writing himself if necessity required it. He was also able to give his clay tablet the correct shape required of a formal letter and well versed in the conventions of corresponding with the king, using the proper forms of polite address. This means that he - and all other officials in similar roles - must have received dedicated training of the same kind as the secretary-scribes in their service. A posting as a secretary-scribe may well have been an entry-level role for an imperial official, as it provided ample insights into the workings of the Empire and would have served as a valuable training ground for future, more independent roles.

About our letter-writer, we do not know anything beyond the information that can be gathered from his letter. This document, however, makes it clear that he could rely on the king knowing who he was, as he introduces himself with only his name; this is typical for higher-ranking state officials, while other correspondents had to make sure that the king could place them by giving titles and affiliations. ${ }^{18}$ Like most individuals active in the imperial administration, this man is likely to have been "summoned to the palace" at a young age to enter into the king's service, ${ }^{19}$ and from that moment onwards, his education would have taken its course at court rather than in his parental home. With the palace housing plenty of young hopefuls destined for a career in the imperial administration, their training in the essential skills of running the Empire would certainly have included acquiring the necessary levels of literacy. Specific information on palace-based training in how to read and write is available only for members of the royal family (male and female), ${ }^{20}$ but as young prince Assurbanipal demonstrably learned how to format and compose letters (as an original writing sample addressed to his royal father Esarhaddon has survived), we can be very certain that the necessary teaching competence was readily available at court.

As stressed by Karen Radner, "Royal Pen Pals: The Kings of Assyria in Correspondence with Officials, Clients and Total Strangers (8th and 7th centuries BCE)", in Official Epistolography and the Language(s) of Power, eds. Stefan Procházka, Lucian Reinfandt \& Sven Tost (Vienna: Verlag der Akademie der Wissenschaften, 2016), 62, 67.

According to a line in a Babylonian commentary to an omen collection, as recognised by Michael Jursa \& Nicla De Zorzi, "The Courtier in the Commentary", Nouvelles Assyriologiques Brèves et Utilitaires 2011, 41-42, "'Courtier' (mār ekalli, literally: 'son of the palace') (means) ša rēši ('courtier'; in Assyrian usage, specifically a eunuch) because as a child [he was summo]ned [to the palace] (and) did not return to (his) father." In the Late Babylonian context in which this commentary was written in Seleucid Uruk, the term ša rēši is indeed best translated as "courtier", but in texts of the Neo-Assyrian period, the term can confidently be understood as referring specifically to a eunuch. For a recent analysis that focuses on the courtier Bel-ibni see Melanie Groß \& Reinhard Pirngruber, "On Courtiers in the Neo-Assyrian Empire: ša-rēši and mazzāz pāni". Altorientalische Forschungen, 41 (2014), 161-75.

20 As discussed by Silvie Zamazalová, "The Education of Neo-Assyrian Princes", in The Oxford Handbook of Cuneiform Culture, eds. Karen Radner \& Eleanor Robson (Oxford: Oxford University Press, 2011), 313-30. 


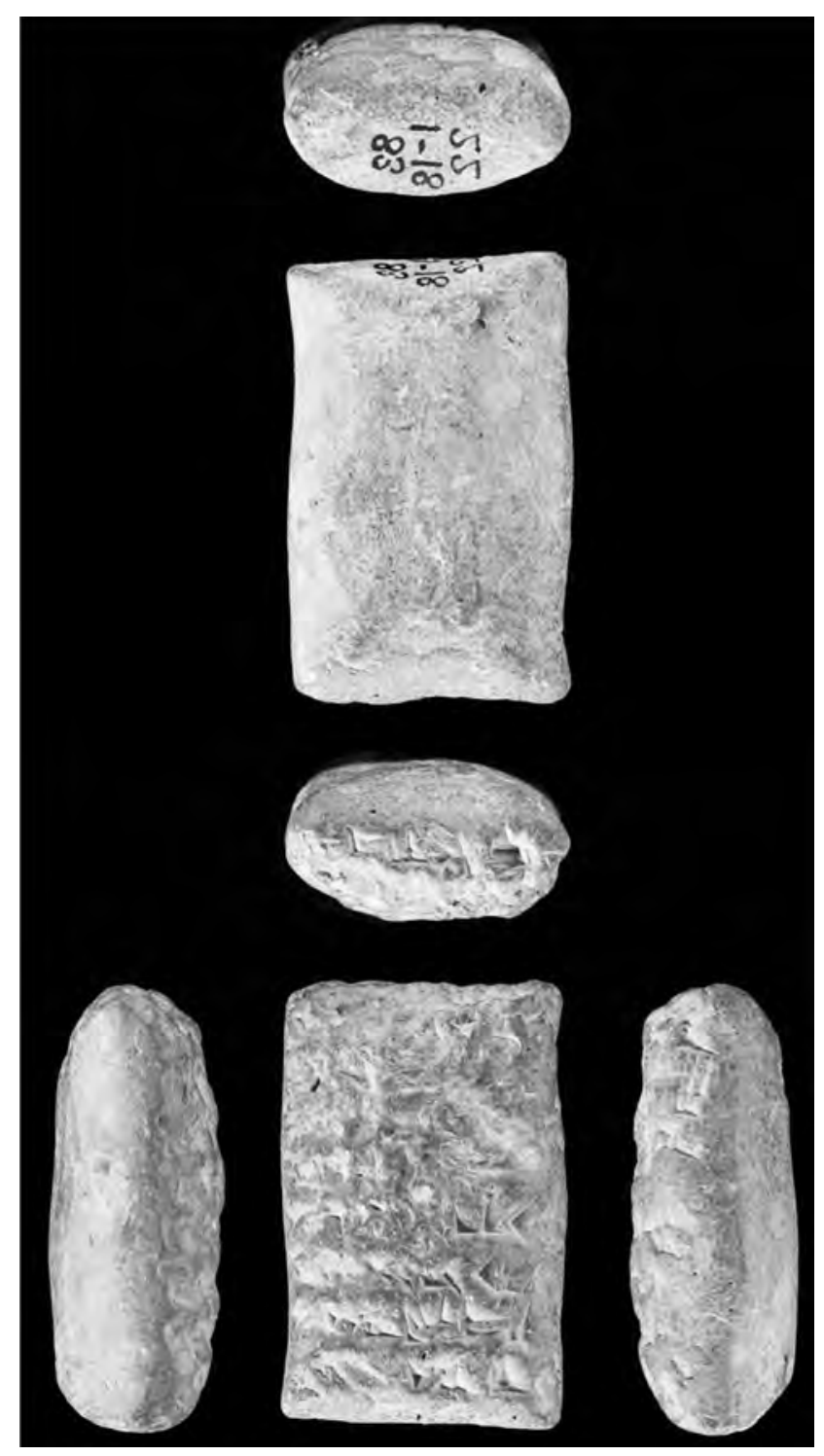

FIGURE 9.3 A cuneiform letter written by young prince Assurbanipal to his royal father ${ }^{21}$

The likely assumption that future imperial administrators, whether to be deployed as secretary-scribes or eventually as provincial governors, were routinely educated as youngsters in reading and writing cuneiform at court explains the great level of homogeneity amongst the letters constituting the Assyrian state correspondence.

21 Edited by Mikko Luukko \& Greta Van Buylaere, The Political Correspondence of Esarhaddon. State Archives of Assyria 16 (Helsinki: Helsinki University Press, 2002), no. 19, discussed in detail by Alasdair Livingstone, "Ashurbanipal: literate or not?" Zeitschrift für Assyriologie und Vorderasiatische Archäologie, 97 (2007): 106-7. 
These issues of scribal training are intimately linked to the general question of the scope and levels of cuneiform literacy in the Neo-Assyrian period. The contemporaneous use of alphabetic scripts has often been taken as an indication that cuneiform literacy may have been far less common than in the 2nd millennium BCE. Simo Parpola argued forcefully against this, and his study of the aforementioned cuneiform letter written personally by an official in need of a new scribe closes with this statement:

I submit that the alleged 'drastic' second-millennium change in Mesopotamian literacy actually never took place, and that the level of literacy in first millennium Mesopotamia was at least as high (if not higher) as in earlier times. $^{22}$

When alphabetic scripts were increasingly widely used in the Neo-Assyrian period, this need not be seen as a result of replacing the cuneiform script. The Empire itself made deliberate use of the most common of those alphabets, the Aramaic one, ${ }^{23}$ as the state operated from the late 9th century BCE a digraphic double-copy system that used the two scripts side by side to document information in Aramaic and in Akkadian. In imperial art, the workings of this administration were routinely depicted as the pairing of a scribe with stylus and clay tablet or wax-covered writing board and another with brush and leather scroll: the first of these scribes records Akkadian in the traditional cuneiform while the second writes Aramaic in the alphabetic script (see above, section 9.1). Already the immediate successor state in Mesopotamia, the Neo-Babylonian Empire did not follow this double-copy practice, and large parts of its bureaucracy relied entirely on Aramaic text written in alphabet script. ${ }^{24}$

As a west Semitic language, Aramaic is closely related to, e.g., Phoenician and Hebrew and, unlike its more distant relatives Assyrian and Babylonian, it was normally recorded in an alphabetic script. Just like cuneiform, the alphabet could be scratched into stone, clay or wax-covered tablets. However, it was far more commonly applied in ink with a brush on a smooth writing surface such as leather or a pottery sherd (producing so-called "ostraca"). To the contemporary speakers of Assyrian and Babylonian, this way of writing was seen as so radically different from the way that cuneiform

Simo Parpola, "The Man Without a Scribe and the Question of Literacy in the Assyrian Empire", in Ana šadê Labnāni lū allik: Beiträge zu altorientalischen und mittelmeerischen Kulturen: Festschrift für Wolfgang Röllig, eds. Beate Pongratz-Leisten, Hartmut Kühne \& Paolo Xella (Kevelaer: Butzon \& Bercker/Neukirchen-Vluyn: Neukirchener Verlag, 1997), 321-2. Cultural History of Aramaic: From the Beginnings to the Advent of Islam, Handbook of Oriental Studies 111 (Leiden: Brill, 2015), 104-56. Contemporary Administrative Letters", in State Correspondences of the Ancient World from the New Kingdom to the Roman Empire, ed. Karen Radner (Oxford: Oxford University Press, 2014), 97. 
characters were created by impressing a stylus into malleable material (designated with the verb šațāru) that it merited its own, distinctive terminology (derived from the verb sepèru). ${ }^{25}$

Given that for the subsequent Neo-Babylonian period a sharp distinction is attested between the "cuneiform scribe" (tupšarru) and the "alphabet scribe" (sēpiru), ${ }^{26}$ it is important to stress that in the Neo-Assyrian period, the term tupšarru (written with the logograms LÚ.DUB.SAR and LÚ.A.BA) served to designate all scribes, regardless of the writing system they used; if it was deemed necessary to further specify, this was done by adding an attribute such as țpšarru aramāyu "Aramaean scribe", or țpšarru muṣurāyu "Egyptian scribe". ${ }^{27}$

Given the Empire's demonstrated interest in alphabet literacy, we must assume that future imperial officials - while having no need to learn Sumerian - were required to acquire the ability to read and write Aramaic as part of their training at court. Now that sizable numbers of Aramaic-language materials from the Neo-Assyrian period are available, mainly because of the numerous text finds during excavations in Syria from the 1990s onwards, it has become clear that the Aramaic textual production across the Empire exhibits great homogeneity in text format, orthography and terminology, which Wolfgang Röllig has seen as a clear indication for standardised training in writing Aramaic. ${ }^{28}$ While concrete evidence for such schooling in a palace context is presently lacking (just like in the case of cuneiform), Aramaic writing exercises are known from a private house of palatial dimensions at Dur-Katlimmu (Tell Sheikh Hamad), the residence of military man and wealthy landowner Šulmu-šarri whose

Michael P. Streck, "Keilschrift und Alphabet", in Hieroglyphen, Alphabete, Schriftreformen: Studien zu Multiliteralismus, Schriftwechsel und Orthographieneuregelungen, eds. Dörte Borchers, Frank Kammerzell \& Stefan Weninger (Göttingen: Seminar für Ägyptologie und Koptologie, 2001), 77.

Cf. Yigal Bloch, Alphabet Scribes in the Land of Cuneiform: Sēpiru Professionals in Mesopotamia in the Neo-Babylonian and Achaemenid Periods (Piscataway: Gorgias Press, 2018).

27 Karen Radner, Die neuassyrischen Privatrechtsurkunden als Quelle für Mensch und Umwelt (Helsinki: The Neo-Assyrian Text Corpus Project, 1997), 80-83.

28 Wolfgang Röllig, Die aramäischen Texte aus Tall Seh Hamad/Dur-Katlimmu/Magdalu (Wiesbaden: Harrassowitz, 2014), 15: "Sowohl diese äußerliche Einheitlichkeit als auch die erstaunlich einheitliche Orthographie und Terminologie lässt vermuten, dass im Assyrerreich eine einheitliche Ausbildung der Schreiber des Aramäischen erfolgte, die damit der Tradition entsprach, die bereits bei den Schreibern der Keilschrift auf Tontafeln eingeübt war. Damit einher ging offenbar auch eine ganz bewusste Schulung in Grammatik und Orthographie des neuen Mediums, das jetzt gleichberechtigt neben die traditionelle Schulung des 'Tafelschreibers' trat." 
title of $\check{s} a$ qurbūti identified him as an intimate of King Assurbanipal. ${ }^{29}$ In his house, where a great many Neo-Assyrian and Aramaic documents have been excavated, two pottery sherds with poorly executed sequences of ink-written Aramaic letters came to light that could be the products of a beginner's first writing experiments with a brush.
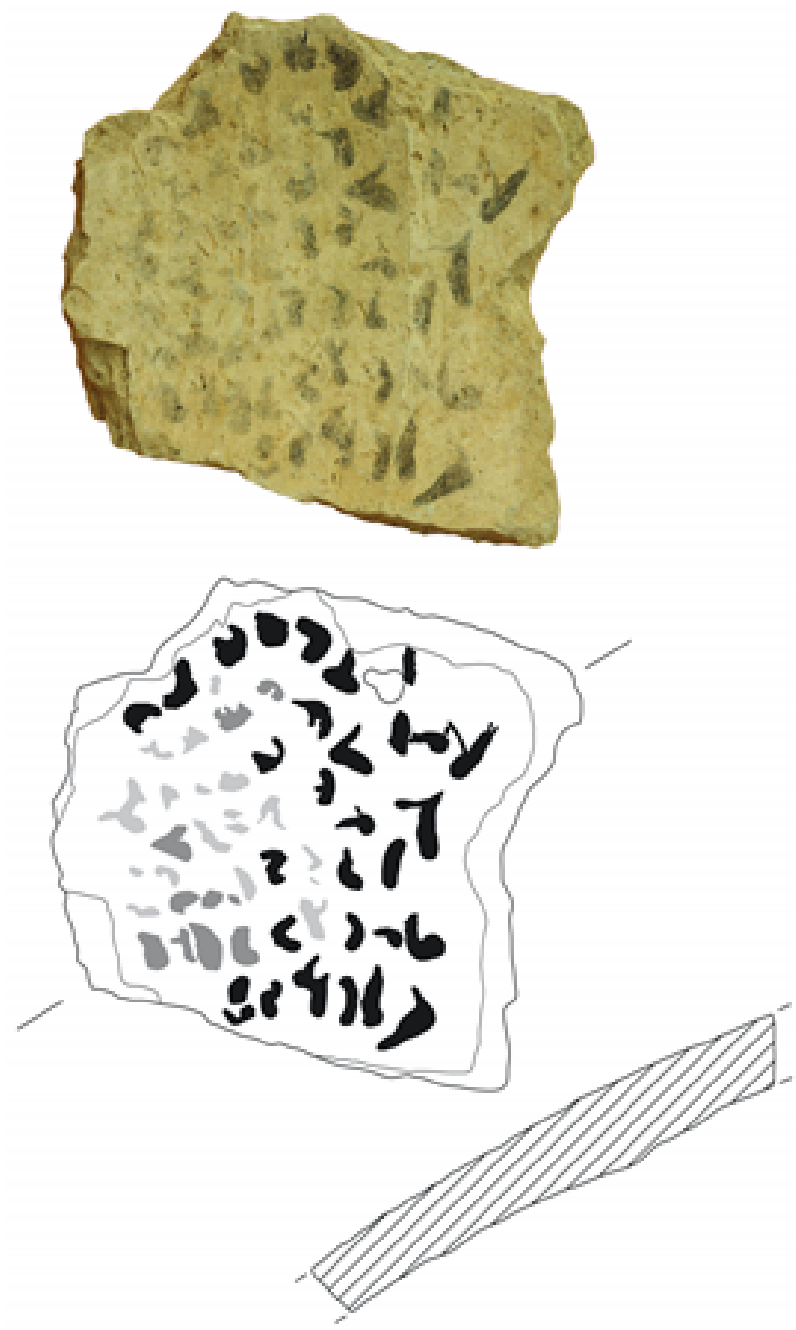

FIGURE 9.4 A writing exercise of alphabetic letters on an ostracon from Dur-Katlimmu ${ }^{30}$

29 For a portrait of Šulmu-šarri and his stately mansion, the so-called "Red House", see Karen Radner, "Economy, Society, and Daily Life in the Neo-Assyrian Period", in A Companion to Assyria, ed. Eckart Frahm (Hoboken: Wiley-Blackwell, 2017), 220-21.

30 Röllig, Die aramäischen Texte, 238 no. 6**. For the other Aramaic ostraca from Dur-Katlimmu see below (section 9.3.2). 

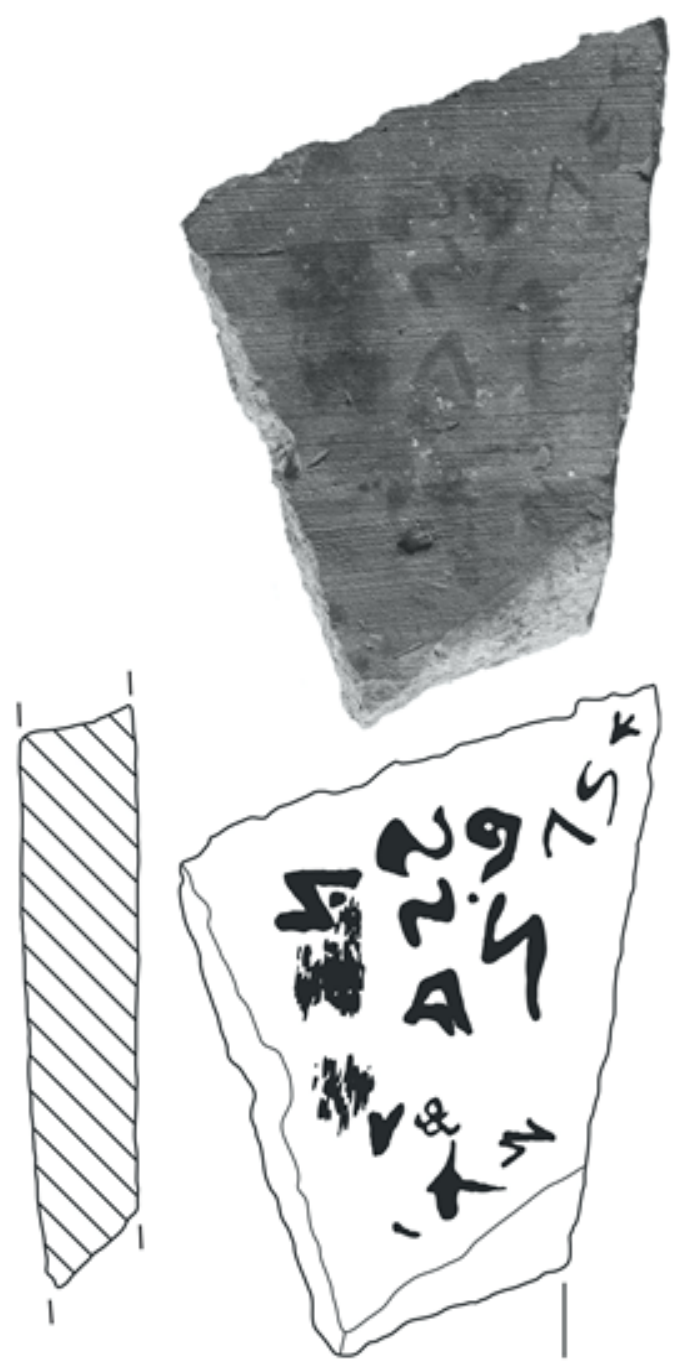

FIGURE 9.5 A writing exercise of alphabetic letters on an ostracon from Dur-Katlimmu ${ }^{31}$

Summing up, we need to appreciate that several modes of scribal training were used in the Neo-Assyrian Empire. On the one hand, the traditional home-schooling continued, as it had underpinned the education of cuneiform learners for centuries. The scholars that we eventually encounter in the royal entourage started their training in this way and continued it later as apprentices in a team headed by a master in the discipline in which they chose to specialise. This was the education path that produced scribes versed in the full arsenal of cuneiform characters as well as the literary lect of Akkadian (Standard Babylonian) and also Sumerian. Crucially, this type of education

31 Röllig, Die aramäischen Texte, 239 no. 7**. For the other Aramaic ostraca from Dur-Katlimmu see below (section 9.3.2). 
opened up access to the numinous and divine - it is clearly an elite phenomenon, so refined that some conservative minds in 7th-century BCE Nineveh thought the idea of the son of a goldsmith in the queen's household (so clearly from a well-to-do and wellconnected background) enjoying such schooling entirely inappropriate. ${ }^{32}$

On the other hand, learning how to read and write the vernaculars Neo-Assyrian and Aramaic in their respective scripts, with a syllabary of no more than 200 cuneiform characters, was part of the training of the imperial officials who typically started their careers path at a young age when they left the family home to enter the palace. These literacy skills were certainly part of a much broader education than that of the scholars as the officials had to be able to function in all sorts of scenarios of the imperial administration, including managing institutional households or entire provinces, their personnel and their finances, brokering treaties, trade agreements and the resettlement of entire communities, leading complex military campaigns, or running ambitious construction projects. The social background of these officials is generally obscure but presumably more diverse than in the first education scenario. While the high degree of standardisation in the textual production in Neo-Assyrian and Aramaic across the Empire can be taken as an indication of the success of this educational pathway to literacy, its particulars are otherwise unknown to us.

\subsection{A SURVEY OF THE SURVIVING TEXTUAL SOURCES}

In this section, we will survey what has survived of the text production of the NeoAssyrian Empire in the various forms of Akkadian in cuneiform (section 9.3.1) and in Aramaic alphabet script (section 9.3.2), emphasising for each genre the specific use of "high" and/or "low" lects and the context within the workings of the imperial administration.

\subsubsection{Texts in Cuneiform}

The majority of extant cuneiform sources from the Neo-Assyrian period consist of clay tablets in various formats. Only royal inscriptions (see below) were routinely

32 As clear from a letter that says: "Parruț, a goldsmith of the household of the queen, has, like the king and the crown prince, bought a Babylonian, and settled him in his own house. He has taught exorcistic literature to his son; extispicy omens have been explained to him, (and) he has even studied gleanings from Enuma Anu Enlil, and this right before the king, my lord! Let the king, my lord, write to his servant on account of this matter." See Mikko Luukko \& Greta Van Buylaere, eds. The Political Correspondence of Esarhaddon. State Archives of Assyria 16 (Helsinki: Helsinki University Press, 2002), no. 65. Despite his training, this very son succeeded his father in the family trade and became a goldsmith, judging from a letter dealing with a precious piece of jewellery, which he personally wrote to the king, identifying himself as "your servant Nabû-sagib, the son of Parruțu, a goldsmith of the household of the queen". See Luukko \& Van Buylaere, The Political Correspondence of Esarhaddon, no. 81. 
recorded also on other types of artefacts, including baked mudbricks, clay prisms and clay cylinders, as such texts could be inscribed on a huge array of objects and materials, such as precious metals and various types of stone. ${ }^{33}$ For all other genres of cuneiform texts, there was one other widely used writing medium in addition to the clay tablet: the wax-covered writing board $(l \vec{e} \hat{u})$. The wooden examples, once surely the most widely available variety, have all perished, and only a few luxury models fashioned from ivory have survived, ${ }^{34}$ although their wax layers are largely gone and with that, their texts. Still, these ivory examples and the depictions of such writing boards in the aforementioned scenes depicting the pair of scribes allow us to reconstruct three types of writing boards: single-leaved; double-leaved with a hinge in the middle so that the object could be shut like a book; and multi-leaved, with the individual boards connected one after the other by hinges and folded together like an accordion.

While all information once recorded on such writing boards has vanished, clay tablets inscribed in cuneiform have survived in large numbers for the Neo-Assyrian Empire. Some types of text, chiefly royal inscriptions and library tablets, were intentionally baked in kilns, but most clay tablets were only air-dried. When the cities in the Empire's heartland in the triangle between Nineveh (Mosul), Arbail (Erbil), and Assur (Qal'at Sherqat) were destroyed from 614 BCE onwards, the flames of destruction consumed all of the leather scrolls and wax-covered tablets, but the fires conserved the clay tablets and made them even more durable. Even when cities and buildings were not destroyed by fire, air-dried clay tablets generally survive well in the ground while organic writing materials slowly, but surely decay. Because of the durability and ubiquity of the clay tablets, the cuneiform remains of the Neo-Assyrian period represent a very wide range of different text genres, which we will briefly survey and contextualise in the workings of the state in the following.

The letters of the royal correspondence and the corpus of private legal texts embody two major pillars of the architecture of the Empire. The letters ${ }^{35}$ represent the means

Cf. Johannes Renger, "Königsinschriften, B: Akkadisch", in Reallexikon der Assyriologie und Vorderasiatischen Archäologie 6, eds. Dietz Otto Edzard, Erich Ebeling, Bruno Meissner, Ernst Weidner \& Wolfram von Soden (Berlin: De Gruyter, 1983), 71-76. Evelyn Klengel-Brandt, "Eine Schreibtafel aus Assur", Altorientalische Forschungen, 3 (1975), 169-71.

35 Most letters were recovered at Kalhu and Nineveh and the majority are available in modern editions by Simo Parpola, The Correspondence of Sargon II, Part I: Letters from Assyria and the West. State Archives of Assyria 1 (Helsinki: Helsinki University Press, 1987); Giovanni B. Lanfranchi \& Simo Parpola, The Correspondence of Sargon II, Part II: Letters from the Northern and Northeastern Provinces. State Archives of Assyria 5 (Helsinki: Helsinki University Press, 1990); Simo Parpola, Letters from Assyrian and Babylonian Scholars. State Archives of Assyria 10 (Helsinki: Helsinki University Press, 1993); Steven W. Cole \& Peter Machinist, Letters from Assyrian and Babylonian Priests to Kings Esarhaddon and Assurbanipal. State Archives 
of a complex imperial communication network that provided the king with constant information, flowing back and forth between the royal court and the numerous territories controlled by the Empire. ${ }^{36}$ They were typically written in Neo-Assyrian script and language, although native Babylonians were free to write in Neo-Babylonian script and language, and the royal chancellery sometimes addressed Babylonian correspondents in letters in Babylonian vernacular, but in Assyrian script. ${ }^{37}$ Scholars writing to their king regularly used citations from scholarly and literary works in the highly codified lect Standard Babylonian to elevate the language of their letters (see also section 9.4). ${ }^{38}$

The corpus of legal texts, on the other hand, bears first-hand witness to the legal and social structures that held the Empire together. ${ }^{39}$ The majority of the known sources are written in Neo-Assyrian language and cuneiform. Sale texts are relatively frequently labelled with short Aramaic summaries in alphabetic script. These conveyance documents were recorded in cuneiform without fail, and it is unclear whether this was due to the existence of binding rules issued by the state or whether the purchasers opted for this option as this was seen as the safest choice: sale texts were known as dannutu "strong (tablet)" and typically kept in family archives for generations, in particular

of Assyria 13 (Helsinki: Helsinki University Press, 1998); Andreas Fuchs \& Simo Parpola, The Correspondence of Sargon II, Part III: Letters from Babylonia and the Eastern Provinces. State Archives of Assyria 15 (Helsinki: Helsinki University Press, 2001); Mikko Luukko \& Greta van Buylaere, The Political Correspondence of Esarhaddon. State Archives of Assyria 16 (Helsinki: Helsinki University Press, 2002); Manfried Dietrich, The Neo-Babylonian Correspondence of Sargon and Sennacherib. State Archives of Assyria 17 (Helsinki: Helsinki University Press, 2003); Frances S. Reynolds, The Babylonian Correspondence of Esarhaddon and Letters to Assurbanipal and Sin-šarru-iškun from Northern and Central Babylonia. State Archives of Assyria 18 (Helsinki: Helsinki University Press, 2003); Mikko Luukko, The Correspondence of Tiglath-pileser III and Sargon II from Calah/Nimrod. State Archives of Assyria 19 (Helsinki: The Neo-Assyrian Text Corpus Project, 2012); and Simo Parpola, The Correspondence of Ashurbanipal, Part I: Letters from Assyria, Babylonia, and Vassal States. State Archives of Assyria 21 (Helsinki: The Neo-Assyrian Text Corpus Project, 2018). These, as well as all other volumes of the State Archives of Assyria series, are available online as part of State Archives of Assyria online (http://oracc.museum.upenn.edu/saao/). A further volume with letters from Assurbanipal's Babylonian correspondence by Grant Frame is under preparation. For state letters found at other sites see Karen Radner, "An Imperial Communication Network: The State Correspondence of the Neo-Assyrian Empire", in State Correspondences of the Ancient World from the New Kingdom to the Roman Empire, ed. Karen Radner (New York and Oxford: Oxford University Press, 2014), 83.

36 As discussed in Radner, "An Imperial Communication Network", 64-93; Radner, "Royal Pen Pals", 61-66.

37 Radner, "An Imperial Communication Network", 78-80.

38 As discussed by Martin Worthington, "Dialect Admixture of Babylonian and Assyrian in State Archives of Assyria VIII, X, XII, XVII and XVIII", Iraq, 68 (2006), 59-84.

39 The legal traditions are discussed by Karen Radner, "Neo-Assyrian Period", in A History of Ancient Near Eastern Law, ed. Raymond Westbrook (Leiden: Brill, 2003), 883-910; and Frederick Mario Fales, "Assyrian Legal Traditions", in A Companion to Assyria, ed. Eckart Frahm (Hoboken: Wiley-Blackwell, 2017), 398-422. 
in the case of real estate. ${ }^{40}$ For debt notes in particular, the creditors clearly felt that there was no great difference in whether a document was drawn up in cuneiform or in alphabetic Aramaic, and although this is far more uncommon, also other types of legal documents were occasionally recorded on sealed clay tablets inscribed in the Aramaic language and script (see further below, section 9.3.2).

There is by now a very sizable body of Aramaic documents known from Assur, Nineveh, Guzana (Tell Halaf), Dur-Katlimmu/Magdalu (Tell Sheikh Hamad), Til-Barsip (Tell Ahmar), Burmarina (Tell Shiukh Fawqani), and the Syrian site of Maallanate, whose modern location has not yet been identified. ${ }^{41}$ Still, such documents have been found in much smaller numbers (around 200 texts) than the considerably more numerous Assyrian sources (around 2000 texts), examples of which have been excavated in over 30 different sites from across the provinces of the Neo-Assyrian Empire. ${ }^{42}$ In Babylonia, on the other hand, legal texts were recorded in Neo-Babylonian language and cuneiform, also during the times of direct Assyrian rule in the 8 th and 7 th century BCE. ${ }^{43}$

Both the letters and the legal texts illuminate the Empire's entanglement in diverse social contexts, from palace and army circles at the heart of the state to craftsmen and deportee households in more provincial settings. These texts also demonstrate that cuneiform writing was routinely practised far away from the principal cultural and administrative centres in the Assyrian heartland during the imperial period. The letters and legal documents also show a remarkable homogeneity in formatting, language and phraseology and a uniformly high production quality, ${ }^{44}$ regardless of where they were written.

On the one hand, this surely indicates centralised training of personnel that was later placed in postings across the Empire where these scribes then produced such texts. While this assumption is easy enough to accept for the letters of the state correspondence (as discussed above in section 9.2), this can only partially explain

Radner, "Schreiberkonventionen im assyrischen Reich", 395-97.

41 See most recently Margaretha Folmer, "Aramaic as a Lingua Franca", in A Companion to Ancient Near Eastern Languages, ed. Rebecca Hasselbach-Andee (Hoboken: Wiley-Blackwell, 2020), 379-81 (with references to the publications).

See the maps referenced in fn. 7. The publications mentioned there, as well as Radner, Die neuassyrischen Privatrechtsurkunden, 8-18, provide access to most of the numerous publications of Neo-Assyrian legal texts, the literature on which is too voluminous to present here. and Archives (Münster: Ugarit-Verlag, 2005). 
how the great homogeneity of the legal documents was achieved. The strong Aramaic language interference in the private legal documents produced in provincial settings such as Dur-Katlimmu indicates that their scribes' primary language was Aramaic, ${ }^{45}$ and these slips make it extremely unlikely that they were centrally trained scribes who had been dispatched to the provinces. Even though Aramaic was their primary language, these same scribes typically have Assyrian names: at Dur-Katlimmu, for example, of the 18 scribes whose names are sufficiently well preserved to allow an attribution, only a single name is Aramaic while all the rest have Assyrian names ${ }^{46}$ - a disproportionate split that does not match the general name distribution otherwise attested at this city, which is far more balanced.

The heavy preponderance of Assyrian names suggests that these scribes were members of the local community who wholeheartedly embraced their Assyrian identity (regardless of whether these were the scribes' original names or names adopted later in life). That cuneiform home-schooling was practised in private contexts at DurKatlimmu is demonstrated by a school exercise tablet, ${ }^{47}$ and this presumably provided the foundation for the scribes' writing skills. Beyond that, the fact that it was essential to their clients that their documents would be acceptable to the state authorities in case of dispute ensured that the scribes strove to create texts according to the rules followed also in the Assyrian heartland. While this suggests some kind of routine contacts between the local scribes and the scribes attached to the provincial administration, we do not know what form this interaction took.

Just like the king's letters, the royal inscriptions are the physical incarnation of the word of the Assyrian ruler. A large corpus of texts attested throughout the imperial period, ${ }^{48}$ they are of key importance for the cohesion of the Neo-Assyrian Empire and celebrate the king and the state. Displayed most prominently in the Assyrian capitals, such inscriptions are part of the fabric also of numerous other sites in the imperial territory. In addition to visible inscriptions, there were hidden inscriptions built into

As demonstrated by the references collected by Karen Radner, Die neuassyrischen Texte aus Tall Šèh Hamad (Berlin: Reimer, 2002), 20-21.

46 Whether a name is Aramaic or Assyrian cannot be decided if only the divine element is preserved and therefore a further three partially preserved names have been excluded here. For the attestations, see Radner, Die neuassyrischen Texte aus Tall Šè Hamad, 22.

47 For the reference, see above fn. 14.

48 For a recent assessment of the corpus of the Neo-Assyrian royal inscriptions see Frederick Mario Fales, "Assyrian Royal Inscriptions: Newer Horizons", State Archives of Assyria Bulletin, 13 (1999-2001): 115-44. Modern editions of these texts can be found in the publication series Royal Inscriptions of Mesopotamia: Assyrian Periods and Royal Inscriptions of the NeoAssyrian Period, also available at http://oracc.museum.upenn.edu/rinap/ and http://oracc. museum.upenn.edu/riao/. 
the fabric of palaces, temples, and fortifications. ${ }^{49}$ The inscriptions were generally composed in the high literary lect Standard Babylonian although Neo-Assyrian language admixture is common. ${ }^{50}$ The texts were typically written in Neo-Assyrian cuneiform script, but occasionally also in archaic writing that was modelled on ancient Babylonian characters. ${ }^{51}$

For his decision-making processes, the Assyrian king relied heavily on divination, ${ }^{52}$ as amply attested in the royal correspondence, which sees scholarly advisers report on observed ominous events and induced oracles and interpret their meaning for the king. ${ }^{53}$ The royal libraries contained thousands of divinatory texts in Standard Babylonian that were compiled, copied, and revised by specialist scholars from originals that came mostly from Babylonia, but also from Assyrian cities like Assur and Kalhu. ${ }^{54}$ The most important reference tools for divination at the Assyrian court were the extispicy series Bārûtu ("Lore of the Diviner", for interpreting the entrails of a sacrificial sheep), as well as the astrological omen series Enūma Anu Enlil ("When the Gods Anu and Enlil"). ${ }^{55}$ Extispicy puts a question to the gods in a strictly observed

Cf. Karen Radner, Die Macht des Namens: Altorientalische Strategien zur Selbsterhaltung (Wiesbaden: Harrassowitz, 2005), 129-55.

50 Best studied for the inscriptions of the 9th century BCE, see Karlheinz Deller, "Assyrisches Sprachgut bei Tukulti-Ninurta II (888-884)", Orientalia Nova Series, 26 (1957): 268-72 and Karlheinz Deller, "Zur sprachlichen Einordnung der Inschriften Aššurnașirpals II (883-859)", Orientalia Nova Series, 26 (1957): 144-56.

51 E.g., the steles of Šamši-Adad V (r. 823-811 BCE) from Kalhu (BM 118892) and Nineveh (BM 115020), see A. Kirk Grayson, Assyrian Rulers of the Early First Millennium BC II (858-745 BC). The Royal Inscriptions of Mesopotamia, Assyrian Periods 3 (Toronto: University of Toronto Press, 1996), 181: A.0.103.1 Ex. 1 (Kalhu) and Ex. 2 (Nineveh). The inscriptions of Sargon II (r. 721-705 BCE) frequently combine the classic signs of the Neo-Assyrian ductus with such archaizing characters, see Karen Radner, "The Stele of Sargon II of Assyria at Kition: A Focus for an Emerging Cypriot Identity?", in Interkulturalität in der Alten Welt: Vorderasien, Hellas, Ägypten und die vielfältigen Ebenen des Kontakts, eds. Robert Rollinger, Birgit Gufler, Martin Lang \& Irene Madreiter (Wiesbaden: Harrassowitz, 2010), 431.

52 As discussed, e.g., by Karen Radner, "Royal Decision-Making: Kings, Magnates, and Scholars", in The Oxford Handbook of Cuneiform Culture, eds. Karen Radner \& Eleanor Robson (Oxford: Oxford University Press, 2011), 361-70; and Stefan M. Maul, Die Wahrsagekunst im Alten Orient: Zeichen des Himmels und der Erde (Munich: C.H. Beck, 2013), 297-313.

53 For their reports see Ivan Starr, Queries to the Sungod: Divination and Politics in Sargonid Assyria. State Archives of Assyria 4 (Helsinki: Helsinki University Press, 1990); Hermann Hunger, Astrological Reports to Assyrian Kings. State Archives of Assyria 8 (Helsinki: Helsinki University Press, 1992); and Simo Parpola, Letters from Assyrian and Babylonian Scholars. State Archives of Assyria 10 (Helsinki: Helsinki University Press, 1993), with detailed commentaries available in Simo Parpola, Letters from Assyrian Scholars to the Kings Esarhaddon and Assurbanipal, Part II (Kevelaer: Butzon \& Bercker/Neukirchen-Vluyn: Neukirchener Verlag, 1983).

See Nils P. Heeßel, "Assyrian Scholarship and Scribal Culture in Ashur", in A Companion to Assyria, ed. Eckart Frahm (Hoboken: Wiley-Blackwell, 2017), 368-77; and Jeanette C. Fincke, "Assyrian Scholarship and Scribal Culture in Kalhu and Nineveh", in A Companion to Assyria, ed. Eckart Frahm (Hoboken: Wiley-Blackwell, 2017), 378-97.

55 Only four of Bārûtu's ten chapters are currently available in full editions (chapters 3-5 and 10), 
ritual context in order to solicit an answer (either "yes" or "no"), and the one hundred tablets of the series Bärûtu detailed the interpretation of all possible variations to be observed in the entrails. The series Enùma Anu Enlil consisted of at least 70 tablets detailing the interpretation of all celestial phenomena that concerned the fate of king and country. Additional works like Šumma àlu ina mēlê šakin ("If a City Is Set on a Height"), which collects terrestrial omens observed within a city, ${ }^{56}$ Šumma izbu ("If the Malformed Birth"), whose omens are derived from malformed births of humans and animals, ${ }^{57}$ or the dream omen series Ziqiqu ("Dreams") ${ }^{58}$ further inform the decision-making processes governing the Empire.

Whether warned by the results of divination or not, the Assyrian crown and the Empire's population more generally considered the rituals and remedies of exorcistic lore (ǎšipūtu) to be crucial tools for protecting them from harm and for securing their personal well-being, health, happiness, and success. ${ }^{59}$ Specialist texts document rituals and procedures that range from simple recipes for medication to instructions for complex ceremonies conducted over several days. Composed in Standard Babylonian, they can either take the form of technical prescriptive and descriptive texts or the form of texts intended for oral recitation, including prayers, invocations, and incantations; some of the latter were written in Sumerian, the ancient language of southern Mesopotamia that had survived in the spheres of scholarship, temple cult, and ritual practice. ${ }^{60}$ At court, exorcists advised the king and routinely provided care in order

and also the astrological series Enūma Anu Enlil has only been edited in part. For references and discussion see Ulla S. Koch, "Sheep and Sky: Systems of Divinatory Interpretation", in The Oxford Handbook of Cuneiform Culture, 447-69; Maul, Die Wahrsagekunst im Alten Orient, 29-130 (extispicy), 237-75 (astrology).

56 Edited by Sally M. Freedman, If a City is Set on a Height: the Akkadian Omen Series Šumma Alu ina Mēlê Šakin, Volume 1: Tablets 1-21 (Philadelphia: Samuel Noah Kramer Fund, 1998); Sally M. Freedman, If a City is Set on a Height: the Akkadian Omen Series Šumma Alu ina Mēlê Šakin, Volume 2: Tablets 22-40 (Philadelphia: Samuel Noah Kramer Fund, 2006); Sally M. Freedman, If a City is Set on a Height: the Akkadian Omen Series Šumma Alu ina Mêlê Šakin, Volume 3: Tablets 41-63 (Winona Lake: Eisenbrauns, 2017). An edition of the remainder of the 100 tablets of the series is currently prepared by Catherine Mittermayer and her team in Geneva.

57 Edited by Nicla De Zorzi, La Serie teratomantica Šumma izbu: testo, tradizione, orizzonti culturali (Padova: s.a.r.g.o.n, 2014).

58 Cf. Sally A. Butler, Mesopotamian Conceptions of Dreams and Dream Rituals (Münster: UgaritVerlag, 1998).

59 Cf. Daniel Schwemer, "Magic Rituals: Conceptualization and Performance", in The Oxford Handbook of Cuneiform Culture, 418-42; Daniel Schwemer, "The Ancient Near East", in The Cambridge History of Magic and Witchcraft in the West: From Antiquity to the Present, ed. David J. Collins (Cambridge: Cambridge University Press, 2015), 17-51.

60 For recent surveys of the sources and their language see Daniel Schwemer, "Form Follows Function'? Rhetoric and Poetic Language in First Millennium Akkadian Incantations", Die Welt des Orients, 44 (2014): 263-88; Daniel Schwemer, "Quellen des Bösen, Abwehrrituale und Erfolgsrezepte: Möglichkeiten und Grenzen einer Systematik der babylonisch-assyrischen 
to ensure the well-being of the king and the royal family: ${ }^{61}$ While the Assyrian royal libraries at Nineveh represent the single most important source of specialist works in terms of numbers of manuscripts and coverage, the frequent discovery of amulet texts and other artefacts connected to the exorcist's craft in various private contexts shows that its appeal reached far beyond court circles. ${ }^{62}$

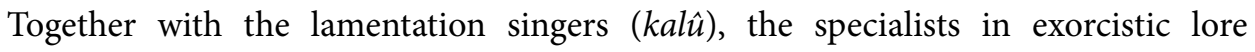
constituted the key participants in the rituals conducted in the temples. Each sanctuary had its own cultic calendar with the performance of specific rituals at fixed dates of the year forming an essential part of the deity's cult and city's communal life. If the Assyrian crown deemed a city and its gods sufficiently prominent, local cults could be promoted to matters of imperial importance. When a temple enjoyed such patronage, the king's participation in the most high-profile temple rituals was required, as their performance now held a key role in the Empire's interests. ${ }^{63}$ The most important corpus of ritual texts comes from Assur, the city of the "national" god Aššur and at the same time the new home of many gods from regions integrated into the Empire, elements of whose cults were incorporated into Aššr's cult. The source material includes on the one hand ritual handbooks offering prescriptive direction for the various participants and on the other hand reports on actual performances of certain temple rituals. ${ }^{64}$ Deeply rooted in local tradition, the temple rituals were typically written in the NeoAssyrian vernacular. ${ }^{65}$ However, as their liturgies owed much to the Empire's long history of contacts with Babylonia, they included Standard Babylonian or Sumerian material. Hence, the bulk of the lamentation singers' performative repertoire consisted of different types of hymns composed in a Sumerian lect called Emesal that exhibit varying degrees of canonisation, from the relatively fixed wording of the bala $\hat{g}$ songs to the fluid adaptability of the šu 'ila compositions. ${ }^{66}$

Magie", in Zauber und Magie im antiken Palästina und in seiner Umwelt, eds. Jens Kamlah, Rolf Schäfer \& Markus Witte (Wiesbaden: Harrassowitz, 2017), 13-40.

As discussed, e.g., by Parpola, Letters from Assyrian and Babylonian Scholars, xiii-xxx and Radner, "Royal Decision-Making", 361-63.

62 E.g., four amulet tablets were excavated in a private house in Assur: Stefan M. Maul, "Schutz für das Haus des Kișir-Aššur: vier Bruchstücke von Tontafelamuletten", in Ausgrabungen in Assur: Wohnquartiere in der Weststadt Teil I, eds. Peter A. Miglus, Karen Radner \& Franciszek M. Stępniowski (Wiesbaden: Harrassowitz, 2016), 135-39.

Cf. Beate Pongratz-Leisten, "The Interplay of Military Strategy and Cultic Practice in Assyrian Politics", in Assyria 1995, eds. Simo Parpola \& Robert M. Whiting (Helsinki: The Neo-Assyrian Text Corpus Project, 1997), 245-52.

Edited by Simo Parpola, Assyrian Royal Rituals and Cultic Texts. State Archives of Assyria 20 (Helsinki: The Neo-Assyrian Text Corpus Project, 2017). Studies in Assyriology in Honour of W. G. Lambert, eds. Andrew R. George \& Irving J. Finkel (Winona Lake: Eisenbrauns, 2000), 389-420. 
With Akkadian and Sumerian bilinguality constituting an important feature in the ritual practice of the Neo-Assyrian period, we need to consider a final genre of cuneiform texts: lexical treatises and sign lists. ${ }^{67}$ Since the first such materials had been compiled in the late 4 th millennium BCE, cuneiform scribes copied old texts, rearranged them, and occasionally composed entirely new ones. Various principles guided the compilation of the different lexical series and are either based on cuneiform signs or on words and/or semantic fields (e.g., wooden objects, geographical names, or legal phraseology). These texts are also amongst the most widespread types of cuneiform texts found across Mesopotamia, Syria, Anatolia, and Iran, even in Egypt. Their wide distribution is partly due to their usefulness in the scribal education: elementary texts, such as basic sign lists and the word list $\mathrm{Ur}_{5}$-ra $=$ hubullu, were commonly used for the basic training of beginner scribes, also in the Neo-Assyrian period. As valuable reference works, lexical texts were also important tools for fullyfledged scribes.

Most lexical texts of the Neo-Assyrian period were Akkadian and Sumerian bilinguals, but there are also monolingual Akkadian compositions that compile rare words and equate them with more common synonyms, such as the series Malku $=\check{s}$ arru. $^{68}$ In doing so, there was significant overlap with the so-called "commentaries", texts that explain difficult passages in a particular composition - an increasingly popular text genre in the first millennium BCE. ${ }^{69}$ By the time of the Neo-Assyrian Empire, the corpus of lexical texts had reached a high level of standardisation, but changes and additions were still possible as cuneiform lexicography continued to be a productive field. Nevertheless, lexical texts clearly had lost their previously prominent position in cuneiform knowledge, and there was no lexicographer amongst the scholars serving the Assyrian king. ${ }^{70}$ However, new compositions like the "Practical Vocabulary of Assur", the "Practical Vocabulary of Nineveh" and the word list Igituh show that the genre was able to address linguistic changes and to cater to newly emerging needs, ${ }^{71}$ and this brings us to Aramaic, whose lexical material finds ample attestation in these new lexical works.

First Millennium BC (Wiesbaden: Harrassowitz, 2014), 214-15.

67 See the survey by Antoine Cavigneaux, "Lexikalische Listen", in Reallexikon der Assyriologie und Vorderasiatischen Archäologie 6, eds. Dietz O. Edzard, Wolfram Von Soden, Dietz O. Edzard, Michael P. Streck (Berlin: De Gruyter 1983), 609-41.

68 Edited by Ivan Hrůša, Die akkadische Synonymenliste malku = šarru: eine Textedition mit Übersetzung und Kommentar (Münster: Ugarit-Verlag, 2010).

69 Eckart Frahm, Babylonian and Assyrian Text Commentaries: Origins of Interpretation (Münster: Ugarit-Verlag, 2011).

70 Niek Veldhuis, History of the Cuneiform Lexical Tradition (Münster: Ugarit-Verlag, 2014), 427-29.

71 Veldhuis, History of the Cuneiform Lexical Tradition, 354-67. 


\subsubsection{Texts in the Alphabet Script}

The surviving material recorded in Aramaic and the alphabetic script from the NeoAssyrian period is available in much more limited quantities than the contemporary cuneiform texts. In antiquity as today, alphabet scribes primarily used organic writing material for their writing. During the Neo-Assyrian period, the most important writing material for Aramaic texts were leather scrolls (sipru), and on rarer occasion presumably also papyrus (niāru) although this plant-based substance would have had to be imported from its native Egypt and would therefore have been much more expensive. ${ }^{72}$ Because of the fact that such material decays unless kept in extremely arid conditions, this work is lost to us today.

Like cuneiform, alphabetic Aramaic was also used for inscriptions on monuments made of a variety of durable materials, most importantly stone. However, very few of the known examples are directly connected to the workings of the Assyrian Empire, as they were typically created in neighbouring states before these were integrated into the provincial system. There are, however, two cases of monuments commissioned by Assyrian governors posted in western provinces that carry also Aramaic inscriptions. The life-sized stone statue of Adda-it'i, governor of Guzana in the early 9th century BCE, was created as an offering to the temple of the stormgod of Sikani (Tell Fekheriyeh) and inscribed on its front with a cuneiform text in Standard Babylonian (albeit with strong Neo-Assyrian interferences) $)^{73}$ and on its reverse in alphabetic Aramaic. ${ }^{74}$ The statue was created at a time when the Assyrian administration in the newly established provinces still greatly relied on individuals of local extraction, and significantly, Adda-it'i calls himself "king of Guzana" in the Aramaic version of the text.

The other set of texts is of considerably later date as Ninurta-belu-ușur, the governor of Hadattu (modern Arslan Tas), identified himself as a subordinate of the well-known commander-in-chief Šamši-ilu who was active in the early 8th century BCE at a time

Note that the Palace Scribe receives "two scrolls of papyrus" (2 ki-ir-ki ni-a-ri) when commodities received as gifts and tribute from the client states are distributed amongst the members of the court of Sargon II: Simo Parpola, The Correspondence of Sargon II, Part I: Letters from Assyria and the West (Helsinki: Helsinki University Press, 1987), no. 34 rev. 19.

As analysed by Frederick Mario Fales, "Le double bilinguisme de la statue de Tell Fekherye", Syria, 60 (1983): 233-50.

74 The monument and its inscriptions are published in Ali Abou-Assaf, Pierre Bordreuil \& Alan R. Millard, La statue de Tell Fekherye et son inscription bilingue assyro-araméenne (Paris: Éditions Recherche sur les civilisations, 1982). Two recent studies, with references to the rich secondary literature, are Frederick Mario Fales \& Giulia F. Grassi, L'aramaico antico: storia, grammarica, testi commentati (Udine: Forum, 2016), 69-81; and Jan Dušek \& Jana Mynářová, "Tell Fekheriye Inscription: A Process of Authority on the Edge of the Assyrian Empire", in The Process of Authority, eds. Jan Dušek \& Jan Roskovec (Berlin: De Gruyter, 2016), 9-39. See also the contribution of Cornelius in this volume. 
when the Assyrian officials in the provinces acted with relative autonomy - especially in the western part of the Empire. ${ }^{75}$ Ninurta-belu-usur built the fortification walls of the city of Hadattu (whose Aramaic name means "The New One") and had his inscriptions engraved on the pairs of lion sculptures guarding two of the three gates. On the Western Gate, a version in Standard Babylonian cuneiform and alphabetic Aramaic was used, while the version of the inscription on the Eastern Gate added also a text in Luwian hieroglyphic script. ${ }^{76}$ As the inscriptions are all written on hidden parts of the sculptures, Ninurta-belu-ușur did not seem to have a contemporary audience in mind when he commissioned them but instead envisaged only future generations of rulers with interest in his works. His choice of languages and scripts likely reflects the fact that these were the ones to have been used in this particular region at the time and, in the case of Luwian, in the recent past: in marked contrast to his superior Šamšiilu who issued his own monuments only in cuneiform, the Assyrian official Ninurtabelu-usur therefore covered all his bases when he also used Aramaic and Luwian for his inscriptions. ${ }^{77}$ His apparent lack of trust in the Assyrian ability to control Hadattu for ever more is remarkable for a servant of the crown, but so is the pride in which he elaborates on his own background.

Beyond these monumental texts and various shorter inscriptions on, e.g., seals, a relatively large number of Aramaic every-day writings from the time of the NeoAssyrian Empire are known in the original. Most importantly, there are numerous legal texts in Aramaic because some types of documents were apparently (also) recorded on clay (see also above, section 9.3.1). In the main, these are debt notes that were inscribed on lumps of clay, formed in a triangular, trapezoid or sometimes also rectangular ${ }^{78}$ shape around a knotted string; such "dockets", as we call them today, were originally tied to something that is now lost: most modern commentators assume this to have

As discussed by Andreas Fuchs, "Der Turtān Šamšīilu und die große Zeit der assyrischen Großen (830-746)", Die Welt des Orients 38 (2008), 61-145.

76 There is no comprehensive publication although there are editions of all texts: John David Hawkins, Corpus of Hieroglyphic Luwian Inscriptions: Inscriptions of the Iron Age (Berlin: De Gruyter, 2000), 246-48, pls. 103-6; Hannes D. Galter, "Die Torlöwen von Arslan Tash", Wiener Zeitschrift für die Kunde des Morgenlandes 97 (2007): 193-211; Wolfgang Röllig, "Die Inschriften des Ninurta-bēlu-ușur, Statthalters von Kār-Salmānu-ašarēd, Teil I", in Of God(s), Trees, Kings, and Scholars: Neo-Assyrian and Related Studies in Honour of Simo Parpola, eds. Mikko Luukko, Sanna Svärd \& Raija Mattila (Helsinki: Finnish Oriental Society, 2009), 265-78; Frederick Mario Fales \& Giulia F. Grassi, L'aramaico antico: storia, grammarica, testi commentati (Udine: Forum, 2016), 82-88. See also Cornelius in this volume.

77 Thus also Hannes D. Galter, "Der Himmel über Hadattu", in Offizielle Religion, lokale Kulte und individuelle Religiosität, eds. Manfred Hutter \& Sylvia Hutter-Braunsar (Münster: UgaritVerlag, 2004), 184, who further emphasizes the choice of deities invoked in the inscriptions: Aššur, the (Aramaean) moongod of Harran and the (Luwian) stormgod of Til-Barsip.

78 E.g., Wolfgang Röllig, Die aramäischen Texte aus Tall Seh Hamad/Dur-Katlimmu/Magdalu (Wiesbaden: Harrassowitz, 2014), 26-27 no. D2. 
been the second part of the contract. ${ }^{79}$ It is important to stress that such dockets are not an exclusively Aramaic text type as very many such tablets were inscribed with Neo-Assyrian cuneiform text: most notable is a group of 40 dockets recording loans of grain from the Nabû temple in Kalhu. ${ }^{80}$

The assumption that there was once a second, now lost part to the docket is due to the conceptual parallel with the other type of debt note of the Neo-Assyrian period. This consists of an inner tablet in landscape format and of the clay envelope that enclosed it. Both parts were inscribed with the same Neo-Assyrian cuneiform text, with the envelope additionally identifying the owner(s) of the seal(s) impressed. ${ }^{81}$ As the dockets are sealed, too, they are generally interpreted as the formal equivalent of the envelope, with the hypothetical second part of the document corresponding to the inner tablet. The idea that that lost part was written on perishable material in Aramaic is widely accepted. ${ }^{82}$ Importantly, this would imply that the dockets written in NeoAssyrian script and language were the accessible part of a bilingual document whose Aramaic text could be checked if needed but, like the inner tablet of the other type of debt note, was essentially meant to be closed off and protected from tampering. We cannot know whether the leather scroll would have been folded up or rolled but either way, its text would have been hidden. Some dockets from Nineveh stand out amongst all other examples, as they were inscribed with text both in Neo-Assyrian cuneiform and alphabetic Aramaic; ${ }^{83}$ we will consider them further below.

In addition to the debt notes in docket shape, there are also a few Aramaic texts recording other types of legal transactions that were inscribed on clay tablets in the rectangular format routinely used also for cuneiform documents. ${ }^{84}$ The widespread

For the term and the shape see most recently Röllig, Die aramäischen Texte, 2, 5-6; and J. Nicholas Postgate in Suzanne Herbordt, Raija Mattila, Barbara Parker, J. Nicholas Postgate \& Donald J. Wiseman, Documents from the Nabu Temple and from Private Houses on the Citadel. Cuneiform Texts from Nimrud 6 (London: British Institute for the Study of Iraq, 2019), 37. Published in Herbordt et al., Documents from the Nabu Temple, 37-113.

81 Radner, "The Relation Between Format and Content of Neo-Assyrian Texts", 68-69.

82 See the literature quoted above, fn. 79 (with further references).

83 Most recently edited by Raija Mattila, Legal Transactions of the Royal Court of Nineveh, Part II: Assurbanipal Through Sin-šarru-iškun. State Archives of Assyria 14 (Helsinki: Helsinki University Press, 2002), nos. 73, 98-99; cf. also the detailed commentaries by Frederick Mario Fales, Aramaic Epigraphs on Clay Tablets of the Neo-Assyrian Period (Rome: La Sapienza, 1986), 135-40 (no. 3), 145-47 (no. 6), 165-70 (no. 15). All these texts are dated to the reign of Assurbanipal. Karen Radner, Cinzia Pappi \& Ezio Attardo, "The Assyrian and Aramaic Texts from Tell Shiukh Fawqani", in Tell Shiukh Fawqani 1994-1998, eds. Luc Bachelot \& Frederick Mario Fales (Padova: s.a.r.g.o.n., 2005), 652-61 nos. 45-50; from Dur-Katlimmu/Magdalu (Tell Sheikh Hamad): Röllig, Die aramäischen Texte, 24-25 no. D1, 226-32 no. 1**; from Til-Barsip: Pierre 
use of Aramaic in private legal contexts is further illustrated by the frequent addition of short Aramaic summaries (today called "labels" or "epigraphs") on Neo-Assyrianlanguage cuneiform tablets. Such annotations were either incised into the leatherhard clay or painted in ink on the tablet's already dry surface. ${ }^{85}$ The present author is intimately familiar with the clay tablets from Dur-Katlimmu (Tell Sheikh Hamad), where a great many such labels were identified, ${ }^{86}$ and can ascertain that the inkwritten annotations that were well visible upon the recovery of the tablets gradually faded away in the months after. It is therefore likely that many more texts amongst the material discovered in the early excavations in the Assyrian heartland at Nineveh and Assur originally bore such ink-written labels but that those vanished before they were properly recorded, as the surviving evidence from these sites consists exclusively of incised summaries. ${ }^{87}$

These short Aramaic labels summarise the content of the cuneiform document, apparently for the benefit of those who could read Aramaic but were less familiar with Neo-Assyrian cuneiform. That such labels exist (but importantly, only in private contexts) emphasises a key point: the distinction between language skills and the ability to read and write this language. While every Aramaic speaker would have been able understand Neo-Assyrian and Neo-Babylonian, and vice versa, thanks to the close linguistic relationship between these languages, this does not mean that these languages would have been just as accessible in writing. There was a strict correlation between the Akkadian language varieties and the comparatively complex cuneiform writing systems (which were different for Neo-Assyrian and Neo-Babylonian) on the one hand, and Aramaic and the simple alphabetic script on the other hand, and the scripts were never switched in the rich sources available for the Neo-Assyrian period. ${ }^{88}$

The apparent usefulness of Aramaic summaries for private legal documents recorded in cuneiform indicates that amongst the Empire's people, the alphabet script was more widely read than cuneiform. On the other hand, there is no evidence for the labelling of Aramaic text with explanative summaries in cuneiform, which signals that alphabetic

Bordreuil \& Françoise Briquel-Chatonnet, "Aramaic Documents from Til Barsib". Abr-Nahrain, 34 (1996/97): 100-7.

85 Wolfgang Röllig, "Keilschrift versus Alphabetschrift: Überlegungen zu den epigraphs auf Keilschrifttafeln", in Writing and Ancient Near Eastern Society: Papers in Honour of Alan R. Millard, eds. Piotr Bienkowski, Christopher Mee \& Elizabeth Slater (London: Bloomsbury, 2005), 119-26.

86 Published in Karen Radner, Die neuassyrischen Texte aus Tall Šèh Hamad. Mit Beiträgen von Wolfgang Röllig zu den aramäischen Beischriften (Berlin: Reimer, 2002).

87 This material has been collected in Fales, Aramaic Epigraphs on Clay Tablets.

88 As discussed by Karen Radner, "Schreiberkonventionen im assyrischen Reich: Sprachen und Schriftsysteme", in Assur: Gott, Stadt und Land, ed. Johannes Renger (Wiesbaden: Harrassowitz, 2011), 389-90. 
writing was deemed fully understandable to all those who read cuneiform. The only apparent exception are the three above-mentioned dockets with Neo-Assyrian and Aramaic text from Nineveh. Each docket is certainly the work of only one scribe, who would likely also have produced the now lost Aramaic document to which these dockets were once tied. The Neo-Assyrian text on the dockets would therefore have been an addition to an otherwise entirely Aramaic document. The existence of these dockets demonstrates unequivocally that some scribes working in Aramaic also mastered the cuneiform script; was a desire to prominently signal their ease with both writing systems and languages the reason why the scribes added the cuneiform text in the first place? The parties and witnesses in one of these legal transactions include highranking military men and the major-domo, ${ }^{89}$ and the other two texts even feature the deputy of the crown prince as the creditor ${ }^{90}$ - certainly all men well worth impressing for a scribe working in the competitive atmosphere of the bustling capital Nineveh. Whatever their reasons, these scribes' work makes it inherently plausible that also the (hypothetical) Aramaic documents attached to the cuneiform dockets were the work of one and the same scribe and lend weight to the assumption that the Aramaic labels on the cuneiform documents were added by the scribes who had written these.

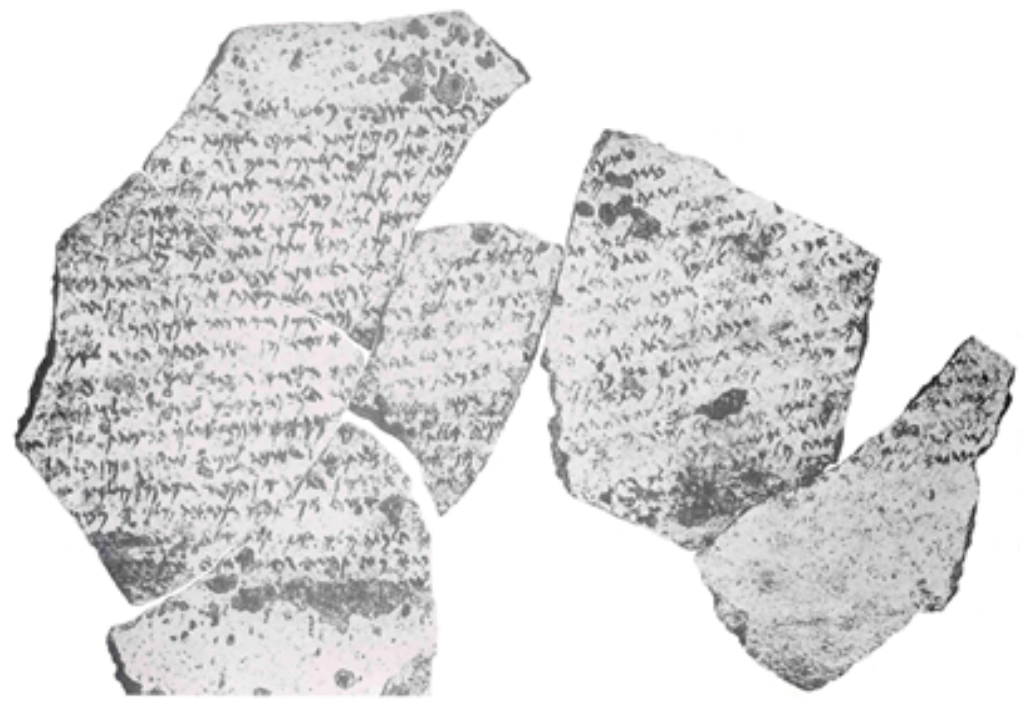

FIgURE 9.6 An Aramaic letter from Assur, known as the "Assur Ostracon"91 also edited, e.g., by Volker Hug, Altaramäische Grammatik der Texte des 7. und 6. Jh.s v. Chr. (Heidelberg: Heidelberger Orient-Verlag, 1993), 19-21; James M. Lindenberger, Ancient Aramaic and Hebrew Letters (Atlanta: Society of Biblical Literature, 2003; 2nd revised Ed.), no. 1 and, most recently, Frederick Mario Fales, "New Light on Assyro-Aramaic Interference: The Assur Ostracon", in CAMSEMUD 2007: Proceedings of the 13th Italian Meeting of Afro-Asiatic 
In addition to these legal documents and summaries, all of which are private in nature, there are two Aramaic ostraca, which can be connected to the workings of the imperial administration. The more famous of the two ostraca is a letter in Aramaic alphabet script, whose contents date it to ca. 650 BCE in the reign of Assurbanipal and whose correspondents are imperial officials (Figure 9.6). The text of the so-called "Assur Ostracon" is painted in ink on a large potsherd $(42 \times 60 \mathrm{~cm})$.

The other, much smaller example was excavated in Kalhu in 1957 and is known as the "Nimrud Ostracon". 92 The potsherd $(5.5 \times 10 \mathrm{~cm})$ was found in the latest occupation level of Room SW1 in Fort Shalmaneser, the "review palace" or arsenal of Kalhu, and therefore dates to the late 7 th century BCE.

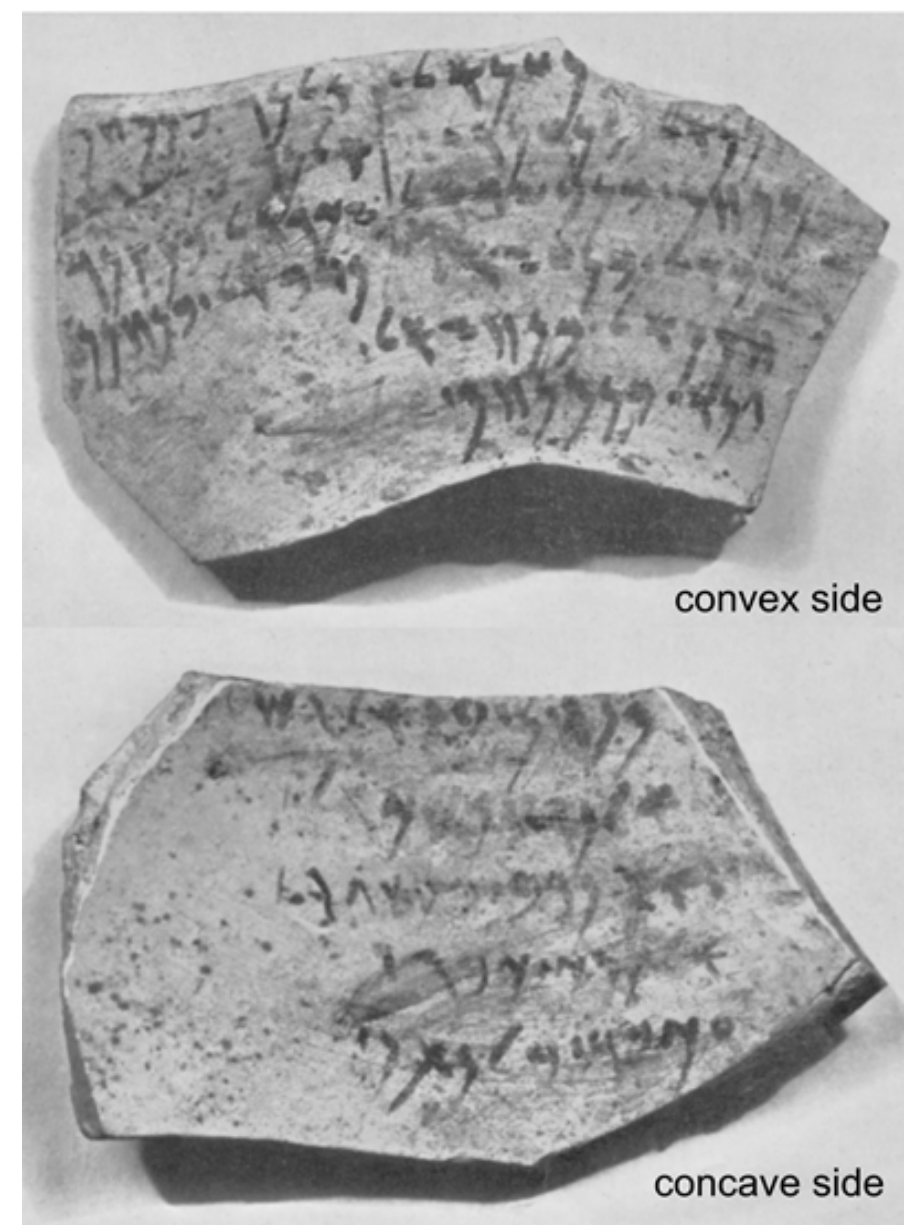

FIGURE 9.7 An Aramaic administrative list from Kalhu, known as the "Nimrud Ostracon"

Linguistics, eds. Frederick Mario Fales \& Giulia F. Grassi (Padova: s.a.r.g.o.n., 2010), 189-204.

92 ND 6231 = IM 73200: J.B. Segal, “An Aramaic Ostracon from Nimrud”, Iraq, 19 (1957): 139-45. 
Aramaic alphabet text is written in black ink on both sides of the sherd. ${ }^{93}$ In total, there are three columns of text listing 15 men with their west Semitic names and filiations (using Hebrew/Phoenician ben rather than Aramaic bar). ${ }^{94}$ Although the lack of additional information obscures the text's purpose, such lists of people are a staple also amongst the administrative documents in Neo-Assyrian language and script, with numerous examples from Kalhu and Nineveh, ${ }^{95}$ and the find context in Fort Shalmaneser strongly suggests that this text is a product of a branch of the palace or state administration. Segal, when publishing this ostracon in 1957, closed his paper with this statement:

It is interesting that this is the first ostracon recovered from Nimrud (Kalhu), and we may confidently affirm that there must still be others of the kind elsewhere, either within this building, or in other parts of the outer town. ${ }^{96}$

However, no further ostraca have been identified at Kalhu. Are the Nimrud Ostracon and the Assur Ostracon anomalies after all? On Middle Eastern excavations focusing on the historical periods, potsherds are usually found in vast quantities, and as most pottery of the Bronze and Iron Age is typically not painted the sherds are habitually soaked in water and scrubbed with a hard brush before the pottery is studied in detail. On excavations in the Levant and in Egypt, pottery is treated differently in this regard, also because painted wares are more frequent - and in these regions, there is rich evidence for the practice of recycling pottery fragments as writing materials. ${ }^{97}$ At the

Segal, "An Aramaic Ostracon from Nimrud", 143 assumes on the basis of the shapes of the letters that the texts on the two sides were the work of two different scribes. It seems more likely to me that the differences can be explained due to the fact that one side is concave and the other convex.

For a time, the document was claimed as an Ammonite text, but this is no longer accepted today; in any case, the script is certainly Aramaic: Matthieu Richelle, "Revisiting the Ammonite Ostraca", Maarav 22 (2018): 50 (with references to previous literature).

E.g., from Kalhu: J. Nicholas Postgate, The Governor's Palace Archive. Cuneiform Texts from Nimrud 2 (London: British School of Archaeology in Iraq, 1973), nos. 113-24; Stephanie M. Dalley \& J. Nicholas Postgate, The Tablets from Fort Shalmaneser. Cuneiform Texts from Nimrud 3 (London: British School of Archaeology in Iraq, 1984), no. 118; from Nineveh: Frederick Mario Fales \& J. Nicholas Postgate, Imperial Administrative Records, Part II. Provincial and Military Administration. State Archives of Assyria 11 (Helsinki: Helsinki University Press, 1995), no. 144 ("memorandum of persons subjected to punishments"); nos. 145-200 ("deportees and displaced persons", although this classification can be contested due to the meagre information given about the individual listed in these texts). Segal, "An Aramaic Ostracon from Nimrud", 145.

97 Cf., e.g., Dirk Schwiderski, Handbuch des nordwestsemitischen Briefformulars (Berlin: De Gruyter, 2000), 237; Christopher A. Rollston, "Epigraphy: Writing Culture in the Iron Age Levant", in The Wiley Blackwell Companion to Ancient Israel, ed. Susan Niditch (Hoboken: Wiley-Blackwell, 2016), 144; Julia Lougovaya, "Writing on Ostraca: Considerations of Material Aspects", in The Materiality of Texts from Ancient Egypt: New Approaches to the Study of Textual Material from the Early Pharaonic to the Late Antique Period, eds. Franciska A.J. Hoogendijk \& Steffie van Gompel (Leiden: Brill, 2018), 52-3. 
Neo-Assyrian site of Dur-Katlimmu, where the frequent discovery of Neo-Assyrian and Aramaic clay documents had raised the reasonable expectation to also encounter Aramaic text on pottery sherds, archaeologists adjusted their methods accordingly and indeed, a number of ostraca were identified, one of which may have been a letter.
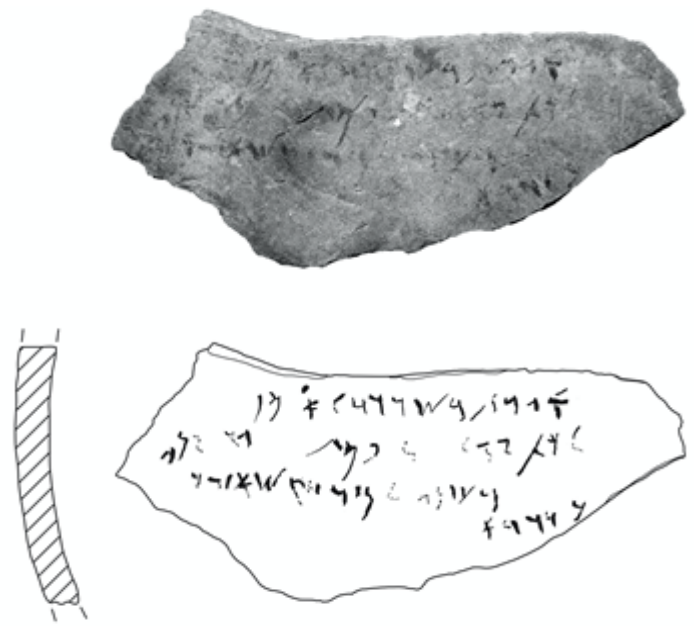

FIGURE 9.8 An Aramaic ostracon from Dur-Katlimmu (Tell Sheikh Hamad) ${ }^{98}$

Therefore, when assessing the writing practices of the Neo-Assyrian Empire, one should assume that writing Aramaic in ink on pot sherds was a widespread phenomenon. Raising awareness about the likely widespread existence of ostraca in the Neo-Assyrian period may hopefully result in further examples to be recovered on Mesopotamian excavations.

But what about the often-quoted letter from the state correspondence of Sargon II (r. 721-705 BCE) that makes it unequivocally clear that this king did not think Aramaic a suitable means of communication with him? This is part of an exchange with a correspondent in the southern Babylonian city of Ur, as documented in Sargon's reply. After quoting his suggestion to write in Aramaic, the king demolishes the very idea:

If it is acceptable to the king, let me write and send my messages to the king on Aramaic documents': Why would you not write and send me messages in Babylonian (Ak-ka-da-at-tu) ? $^{99}$ Really, the message which you write in it must be drawn up in this very manner - this is a fixed regulation! ${ }^{100}$ Ancient and Modern, ed. J. Nicholas Postgate (Cambridge: Cambridge University Press, 2007), 31-71. 
Sargon's final instructions of how to write a proper letter refer to the format of the very document in which they are written: a clay tablet of the typical letter shape in portrait format, inscribed in cuneiform script and the contemporary Neo-Babylonian language - but not Neo-Assyrian, as Sargon and the other Assyrian rulers never expected their Babylonian correspondents to address them in this way. The Assyrian kings always wrote their own letters to Babylonian recipients in Babylonian, as is also the case with this specific letter. ${ }^{101}$ This practice should be seen as part of a wider Assyrian strategy in Babylonia that sought to restore and preserve ancient cultural traditions, and Sargon's directive to his correspondent therefore must not be interpreted as a general assault against the use of Aramaic as an epistolary language but as a deliberate attempt to shore up of traditional Babylonian customs in Ur.

In an attempt to explain why there is considerably less cuneiform material available for the state correspondence of the 7th century BCE, Simo Parpola postulated that Sargon's successors permitted their correspondents the use of Aramaic, and that the resulting leather documents did not survive. ${ }^{102}$ The Assur Ostracon offers some support for this view. Although it is not part of the royal correspondence, its content concerns political and military matters and the correspondents were certainly Assyrian officials in the service of King Assurbanipal (r. 668-631 BCE). There is repeated mention of letters being written and sent, including one to the king (1. 6), and while there is no indication of these letters' script and language, the sheer existence of the Assur Ostracon itself makes it difficult to argue that they all must have been clay tablets inscribed in cuneiform. After all, even if we wanted to interpret Sargon's instructions to his Urukean correspondent as a general condemnation of Aramaic letter-writing, his successors may have felt less restrictive about the use of Aramaic as an epistolary language in their correspondence.

However, if state officials ever wrote Aramaic letters, these too would have had to be sealed with the golden signet ring bearing the iconic image of the king as lion-slayer that identified them as the king's representatives in the imperial administration. ${ }^{103}$

Archives of Assyria 17 (Helsinki: Helsinki University Press, 2003), no. 2: II. 15-22. The passage is also discussed in the contribution of Berlejung in this volume.

101 Other examples: Dietrich, The Neo-Babylonian Correspondence, nos. 1, 3-6 (Sargon II); Frances S. Reynolds, The Babylonian Correspondence of Esarhaddon and Letters to Assurbanipal and Sin-šarru-iškun from Northern and Central Babylonia. State Archives of Assyria 18 (Helsinki: Helsinki University Press, 2003), nos. 1-5 (Esarhaddon).

102 Simo Parpola, "Assyrian Royal Inscriptions and Neo-Assyrian Letters", in Assyrian Royal Inscriptions: New Horizons in Literary, Ideological and Historical Analysis, ed. Frederick Mario Fales (Rome: Centro per le antichita e la storia dell'arte del Vicino Oriente, 1981), 122-3.

103 As discussed by Karen Radner, "The Delegation of Power: Neo-Assyrian Bureau Seals", in L'archive des Fortifications de Persépolis: État des questions et perspectives de recherches, eds. Pierre Briant, Wouter F.M. Henkelman \& Matthew W. Stolper (Paris: Éditions de Boccard, 
At Nineveh, very many clay sealings have been found that bear the impression of this imperial seal, and some of these may well have served as sealings for letters written on organic materials. ${ }^{104}$ So far, only one sealing of a variant of the imperial seal, which shows the lion-slaying king with the emblems of the crown-prince (Y-shaped cross) and the queen (scorpion), could be securely identified as having been applied to papyrus, as its backside shows the fold in the papyrus document, which was bound together with string.

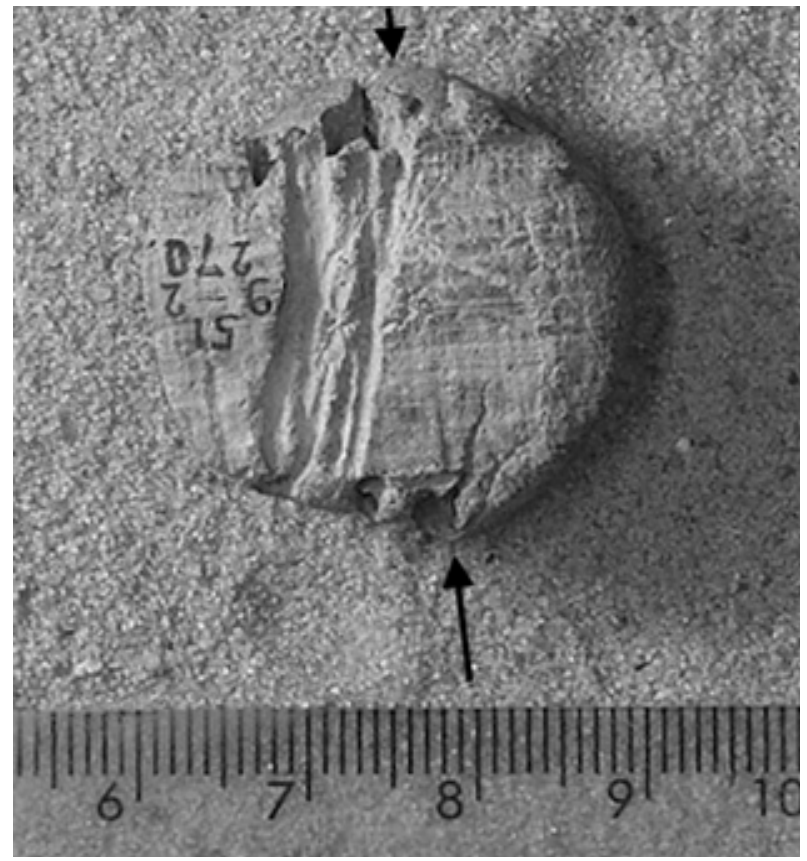

FIGURE 9.9 The reverse of a clay sealing impressed with the imperial seal, showing the imprint of a folded papyrus (marked with black arrows) ${ }^{105}$

Many of the sealings tentatively identified as having been fastened to wooden writing boards could just as well have come from papyrus documents, as the imprints of wood and papyrus on clay resemble each other. ${ }^{106}$

2008), 487-90; further Radner, "An Imperial Communication Network", 67-8, 77-8.

104 For this material see Suzanne Herbordt, Neuassyrische Glyptik des 8.-7. Jh. v. Chr. (Helsinki: The Neo-Assyrian Text Corpus Project, 1992), 124-7.

105 BM $84751=51-9-2,270$ (British Museum), discussed by Herbordt, Neuassyrische Glyptik, 68, 126 no. 79, 133, pl. 35: 7; Radner, "The Delegation of Power", 500-1 with Figure 18; Terrence C. Mitchell \& Ann Searight, Catalogue of the Western Asiatic Seals in the British Museum: Stamp Seals, III: Impressions of Stamp Seals on Cuneiform Tablets, Clay Bullae, and Jar Handles (Leiden: Brill, 2008), 98 (no. 212).

106 For references to impressions of the imperial seal on writing boards (or possibly in some cases papyrus) see Radner, "The Delegation of Power", 490-4. 


\subsection{DIGLOSSIA IN THE NEO-ASSYRIAN EMPIRE}

Summing up, the textual production of the Assyrian Empire was produced by scribes trained in (at least) two different educational settings: on the one hand, home-schooling in the family, that for some was followed by an apprenticeship in a team headed by an expert in e.g. divination for further specialisation; and on the other hand, far removed from one's family since childhood to train at court in a proto-boarding school setting for imperial servants.

The latter produced personnel with reading and writing skills in cuneiform and the alphabetic script to match the bilingual nature of the Assyrian administration. We have argued that all members of the imperial administration were trained as scribes, but that writing was only for some their primary task (either because they were at an early stage of their career or because they were never promoted to more independent roles). While the high literary lect Standard Babylonian would have been readily understandable to this group of people, they would not have been required to compose texts in this elevated language variant. Instead, the administration operated with a digraphic writing system and a choice of vernacular languages that massively privileged the Semitic speakers amongst its subjects: cuneiform writing was used to record two distinct, vernacular forms of Akkadian (Neo-Assyrian and Neo-Babylonian) while the alphabet script was used for Aramaic as a third vernacular. Employing these three lects seems to have allowed effective communication with the vast majority of the Empire's population.

The reading and writing skills of the imperial servants were matched elsewhere in the holdings of the Empire where home-schooling produced people with cuneiform and alphabetic literacy skills, typically in family contexts with clearly expressed sympathies for Assyrian culture (as best expressed by their choice of names). It is of course possible that there were also social contexts where alphabetic and/or cuneiform writing was practised entirely separately from each other, but it must be pointed out that the available Aramaic material available for the Neo-Assyrian period has always been found in conjunction with cuneiform texts in an Akkadian vernacular.

The fact that so much more of the surviving textual production is written in cuneiform than in alphabetic Aramaic tends to obscure that Aramaic held an equal status to the Akkadian vernaculars. On the one hand, the uneven survival of sources reflects the different materials used for writing. But on the other hand, this is due to the fact that the entire production of the royal inscriptions and of the traditional Mesopotamian scholarly disciplines was written in the highly codified literary lect of Standard Babylonian, which was recorded in cuneiform (as was also Sumerian, which was used in certain contexts). All such material, however, was the work of highly trained 
specialists who were not at all representative for the levels of literacy of Neo-Assyrian society at large. These specialist scribes gravitated towards the royal court, where the king's patronage would have given them social status and material benefits, but the state did not initiate their training.

Overall, the scribal production of the Neo-Assyrian period must therefore be described as diglossic. ${ }^{107}$ The phenomenon of diglossia in the Neo-Assyrian Empire has not yet been the focus of in-depth research, but there are some studies focusing on language admixture in specific bodies of texts that demonstrate the potential of the approach.

Although the close language contacts between Aramaic and Akkadian in the NeoAssyrian period have long been a topic of research, ${ }^{108}$ appreciating the different status and roles of the Akkadian language variants enhances awareness for the nuances of these contacts. Due to the preponderance of the available sources, the focus of research has concentrated on language admixture in the Aramaic and Neo-Assyrian legal texts. On the one hand, there is clear evidence for the systematic borrowing of Neo-Assyrian legal terminology in Aramaic documents where these lexemes have become standard items in the vocabulary (e.g., dannutu $>d n t$ "sale text"; kaspu $>$ ksp "price", limmu $>\operatorname{lm}$ "eponym year"). ${ }^{109}$ Aramaic language admixture in Neo-Assyrian documents, on the other hand, is a distinct feature of the textual production in the western provinces of the Empire. In the texts from Dur-Katlimmu (Tell Sheikh Hamad), for example, unintentional interference of Aramaic is in evident in grammar and morphology, especially in certain verbal forms (namely the stative, which has no formal equivalent in Aramaic). ${ }^{110}$

Appreciating the phenomenon of diglossia is especially important when working with Akkadian texts. Some previous work has called attention to specific contexts of language admixture. Karlheinz Deller's pioneering work on the royal inscriptions of the early 9th century BCE highlighted already in the 1950s the Neo-Assyrian vernacular's interference with Standard Babylonian text production when analysing the vernacular's language admixture in the inscriptions of Tukulti-Ninurta II (888-884 BCE) and

107 For the term and its usage in linguistics see Charles A. Ferguson, "Diglossia", Word, 15 (1959): 325-40. For a recent attempt to use the term for the ancient linguistic environment of the Levant, albeit in the first centuries CE, see Hughson T. Ong, "Ancient Palestine Is Multilingual and Diglossic: Introducing Multilingualism Theories to New Testament Studies", Currents in Biblical Research, 13 (2015): 330-50.

108 For a recent survey see Michael P. Streck, "Akkadian and Aramaic Language Contact", in The Semitic Languages: An International Handbook, eds. Stefan Weninger, Geoffrey Khan, Michael P. Streck \& Janet C.E. Watson (Berlin: De Gruyter, 2011), 416-24.

109 Fales, "New Light on Assyro-Aramaic Interference: The Assur Ostracon", 189-204 (with previous literature).

110 Radner, Die neuassyrischen Texte aus Tall Šêh Hamad, 20-1. 
Ashurnasirpal II. ${ }^{111}$ In the 1980s, his student Kazuko Watanabe documented in her doctoral dissertation the interference between the Neo-Assyrian and Neo-Babylonian vernaculars in the long succession treaty of Esarhaddon, ${ }^{112}$ likely the result of several authors of Assyrian and Babylonian extraction working together to create the long composition in a strictly limited amount of time, as it needed to be ready in dozens, if not hundreds of copies at a set date. ${ }^{113}$

More recently, a 2006 paper of Martin Worthington explored language admixture in the Neo-Assyrian and Neo-Babylonian letters written by scholars in the royal entourage to Esarhaddon and his successor Assurbanipal. ${ }^{114}$ Most importantly, Worthington's analyses highlight how frequent Standard Babylonian language admixture is attested in Neo-Assyrian and Neo-Babylonian letters, taking the form of consciously switching into Standard Babylonian when quoting works of scholarship in the scholars' letters, typically in order to make their claims verifiable, or when citing works of literature, usually as a rhetorical flourish to strengthen their point and to show their erudition. This intentional code-switching serves to elevate their text, as Standard Babylonian is of course the lect with the higher literary and scholarly status. On the other hand, Worthington also identified instances of switching between the two vernaculars, namely Neo-Assyrian language admixture in Neo-Babylonian letters, although this is relatively rare. In these cases, the text typically switches into Neo-Assyrian in the writer's response to previously received correspondence, and it is a matter of perspective whether this is seen as intentional code-switching or unintentional interference.

Although limited in scope, these studies clearly demonstrate that the vernaculars NeoAssyrian and Neo-Babylonian and the literary lect Standard Babylonian interacted differently with each other in different text genres and that depending on context, language admixture could be due to standardised borrowing, intentional codeswitching or unintentional interference, or a combination of these. There is much scope for further work, especially for quantitative analyses across genres; it is hoped that the increasing availability of digital datasets in standardised format will encourage such studies and help to further elucidate the nuanced ways in which diglossic language

111 Karlheinz Deller, "Assyrisches Sprachgut bei Tukulti-Ninurta II. (888-884)", Orientalia Nova Series, 26 (1957): 268-72; Karlheinz Deller, "Zur sprachlichen Einordnung der Inschriften Aššurnașirpals II. (883-859)”, Orientalia Nova Series 26 (1957): 144-56.

112 Kazuko Watanabe, Die adê-Vereidigung anlässlich der Thronfolgeregelung Asarhaddons (Berlin: Mann, 1987), 43-4.

113 Cf. Jacob Lauinger, "Neo-Assyrian Scribes, 'Esarhaddon's Succession Treaty', and the Dynamics of Textual Mass Production", in Texts and Contexts: Approaches to Textual Circulation and Transmission in the Cuneiform World, eds. Paul Delnero \& Jacob Lauinger (Berlin: De Gruyter, 2015), 285-314.

114 Martin Worthington, "Dialect Admixture of Babylonian and Assyrian in State Archives of Assyria VIII, X, XII, XVII and XVIII", Iraq, 68 (2006): 59-84. 
practices shaped the communication strategies and textual production of different groups in the Neo-Assyrian Empire.

\section{References for Figures}

Figure 9.1 The many languages of the Neo-Assyrian Empire. Prepared by the author on the basis of a map by Andreas Fuchs published in Historischer Atlas der antiken Welt, eds. AnnaMaria Wittke, Eckart Olshausen \& Richard Szydlak (Stuttgart: J.B. Metzler, 2007), 49.

Figure 9.2 A cuneiform letter written by a state official in need of a scribe. British Museum, K 652. Photograph from https://cdli.ucla.edu/ObjectID=P334097, courtesy of The Trustees of the British Museum.

Figure 9.3 A cuneiform letter written by young prince Assurbanipal to his royal father. British Museum, 1883-1-18, 22. Photograph from https://cdli.ucla.edu/ObjectID=P313562, courtesy of The Trustees of the British Museum.

Figure 9.4 A writing exercise of alphabetic letters on an ostracon from Dur-Katlimmu (Tell Sheikh Hamad) with the measurements $88 \times 95 \mathrm{~mm}$. Published by Wolfgang Röllig, Die aramäischen Texte aus Tall Seh Hamad/Dur-Katlimmu/Magdalu (Wiesbaden: Harrassowitz, 2014), 238 no. $6^{* *}$. Archaeological Museum Deir ez-Zor, SH 94/6145/0055. (c) Tell Sheikh Hamad Archive, Freie Universität Berlin. Courtesy of Hartmut Kühne.

Figure 9.5 A writing exercise of alphabetic letters on an ostracon from Dur-Katlimmu (Tell Sheikh Hamad) with the measurements $47 \times 59 \mathrm{~mm}$. Published by Wolfgang Röllig, Die aramäischen Texte aus Tall Seh Hamad/Dur-Katlimmu/Magdalu (Wiesbaden: Harrassowitz, 2014), 239 no. $7^{\star \star}$. Archaeological Museum Deir ez-Zor, SH 98/6951/0219. () Tell Sheikh Hamad Archive, Freie Universität Berlin. Courtesy of Hartmut Kühne.

Figure 9.6 An Aramaic letter from Assur, known as the "Assur Ostracon". Vorderasiatisches Museum Berlin, VA 8384. Photograph reproduced from Mark Lidzbarski, Altaramäische Urkunden aus Assur (Leipzig: Hinrichs, 1921), pl. 1.

Figure 9.7 An Aramaic administrative list from Kalhu, known as the "Nimrud Ostracon". Iraq Museum, IM 73200 (ND 6231). Photographs reproduced from J.B. Segal, "An Aramaic Ostracon from Nimrud", Iraq, 19 (1957): pl. XXXIV. Courtesy of The British Institute for the Study of Iraq.

Figure 9.8 An Aramaic ostracon from Dur-Katlimmu (Tell Sheikh Hamad), possibly a letter as the text starts with the word 'grt "letter". Published by Wolfgang Röllig, Die aramäischen Texte aus Tall Seh Hamad/Dur-Katlimmu/Magdalu (Wiesbaden: Harrassowitz, 2014), 254-55 no. 22**. Archaeological Museum Deir ez-Zor, DeZ 5688 (SH 86/8979/0066). (C) Tell Sheikh Hamad Archive, Freie Universität Berlin. Courtesy of Hartmut Kühne.

Figure 9.9 The reverse of a clay sealing impressed with the imperial seal, showing the imprint of a folded papyrus (marked with black arrows). British Museum, BM 84751 (51-9-2, 270). Photograph by Karen Radner, courtesy of The Trustees of the British Museum. 